\title{
Patterns of E74A RNA and protein expression at the onset of metamorphosis in Drosophila
}

\author{
LYNN BOYD, ERIN O'TOOLE and CARL S. THUMMEL \\ Howard Hughes Medical Institute, Eccles Institute of Human Genetics, University of Utah, Salt Lake City, Utah 84112, USA
}

\section{Summary}

Metamorphosis in Drosophila is triggered by a pulse of the steroid hormone ecdysone at the end of larval development. Ecdysone initiates a genetic hierarchy that can be visualized as a series of puffs in the larval salivary gland polytene chromosomes. The $E 74$ gene is responsible for the early ecdysone-inducible puff at position 74EF and encodes two related DNA-binding proteins which appear to play a regulatory role in the hierarchy. Here we describe the spatial and temporal patterns of E74A RNA and protein expression at the onset of metamorphosis. We use in situ hybridization, antibody stains, and western and northern blot analyses to follow $E 74 A$ expression from its initial appearance as nascent transcripts on the polytene chromosomes, to spliced mRNA, to post-translationally modified nuclear $E 74 A$ protein. $E 74 A$ is expressed in a wide variety of late-third instar tissues, suggesting that it plays a broad pleiotropic role in response to the hormone. In early prepupae, when the overall levels of E74A mRNA are decreasing, relatively high levels of $E 74 A$ RNA persist in the gut, peripodial membranes of the imaginal discs, and proliferation centers of the brain. The spatial distribution of nuclear $E 74 A$ protein correlates with the RNA distribution with the single exception that no $E 74 A$ protein can be detected in the proliferation centers of the brain. There is also a temporal discrepancy between $E 74 A$ mRNA and protein accumulation. The peak of $E 74 A$ protein induced by the late larval ecdysone pulse follows the peak of $E 74 A$ mRNA by $\sim 2 \mathrm{~h}$. This delay is not seen in $10 \mathrm{~h}$ prepupae, when the next pulse of ecdysone induces the simultaneous expression of $E 74 A$ mRNA and protein. We discuss possible mechanisms for post-transcriptional regulation of $E 74 A$ expression and suggest that the unusually long and complex $5^{\prime}$ leader in the $E 74 A$ mRNA may regulate its translation.

Key words: ecdysone, metamorphosis, Drosophila, RNA localization, post-transcriptional regulation.

\section{Introduction}

The life cycle of the fruit fly, Drosophila melanogaster, is interrupted by a dramatic morphological transformation from the relatively immobile larva to the highly motile and reproductively active adult fly. This complete metamorphosis is triggered by a pulse of the steroid hormone $20 \mathrm{OH}$-ecdysone (henceforth referred to as ecdysone) at the end of larval development. During metamorphosis the imaginal cells within the larva develop to form their predetermined adult structures. The imaginal discs evaginate and differentiate to form the external appendages and cuticle of the head and thorax, as well as part of the reproductive system, while the abdominal histoblasts proliferate to form the abdominal cuticle. Simultaneously, clusters of imaginal cells develop into the internal adult organs and replace the larval organs which undergo histolysis. A few tissues remain functional through both larval and pupal stages. These include the fat bodies, which disperse and then reaggregate, the brain, which undergoes significant growth and remodelling, and the
Malpighian tubules (Bodenstein, 1965; Robertson, 1936).

The effects of ecdysone are not limited to metamorphosis, but rather extend throughout the life cycle of Drosophila. The first ecdysone pulse, of unknown biological function, follows germ band retraction during embryogenesis. Two more pulses, during the first and second larval instars, trigger a developmental response that is restricted to the epidermis and leads to molting of the larval cuticle. This contrasts sharply with the pulse of ecdysone at the end the third larval instar which affects virtually all tissues as it triggers the onset of metamorphosis. A subsequent ecdysone pulse leads to head eversion, marking the prepupal-pupal transition, and a broad peak of ecdysone during pupal development is thought to be required for progression through metamorphosis (Richards, 1981).

Insights into the regulatory mechanisms whereby ecdysone coordinates these tissue-specific developmental changes have been inferred from studies of the puffing patterns of the larval salivary gland polytene chromosomes. As observed originally by Becker (1959) 
and Clever and Karlson (1960) and described in detail by Ashburner (Ashburner, 1967; Ashburner et al. 1974), ecdysone induces two temporally distinct sets of puffs - six early puffs followed several hours later by more than 100 late puffs. These two sets of puffs are distinguished by several criteria. First, the early puffs form within minutes after the addition of ecdysone while the late puffs appear with a delay of $2-10 \mathrm{~h}$. Second, the early puffs appear to form a single temporal class that is coordinately regulated while the late puffs can be subdivided into different groups based on their times of induction and responses to ecdysone withdrawal. Third, induction of the early puffs is unaffected by the addition of protein synthesis inhibitors while regression of the early puffs and induction of the late puffs is effectively blocked under these conditions. Fourth, the early puffs respond in a stepwise manner over an $\sim 600$-fold range of ecdysone concentrations while the late puffs show more of a threshold response, over only a 4- to 5-fold range in concentration (Ashburner et al. 1974).

Based on these and other results, Ashburner et al. (1974) proposed a model to account for the genetic control of polytene chromosome puffing by ecdysone. According to this model, ecdysone directly activates the small set of early puffs (genes) which function as regulatory intermediates that both repress their own expression and induce the large set of late puffs (genes). The early genes thus determine the amount of their own expression by feedback regulation, as well as dictate the timing of late gene activation. The late genes, in turn, are thought to play a direct role in initiating metamorphosis.

To account for the effects of ecdysone at other times during development and in target tissues other than the larval salivary gland, Burtis et al. (1990) have proposed an extension of the Ashburner model designated the tissue coordination model. This model predicts that regulatory hierarchies similar to that proposed by Ashburner are induced by ecdysone in a spatially and temporally defined manner. According to this model, the complex regulatory information required for the diversity of morphogenetic responses to ecdysone is encoded within overlapping sets of early ecdysoneinducible genes. By interacting in a combinatorial manner, these early genes activate unique sets of late genes that dictate the morphological and functional properties of each tissue at each stage in its development.

We are testing these models of ecdysone action by studying the regulation of $E 74$, the ecdysone-inducible gene responsible for the early puff at position $74 \mathrm{EF}$ in the polytene chromosomes. Mutations within $E 74$ cause lethality during pupal development, indicating that this gene performs an essential function during metamorphosis (Burtis, 1985). E74 is composed of two overlapping transcription units, $E 74 A$ and $E 74 B$, that initiate from distinct promoters but share a common polyadenylation signal. E74 $A$ encodes a $60 \mathrm{~kb}$ primary transcript that is spliced to form a $6 \mathrm{~kb}$ mRNA. Aside from the unusual length of its transcription unit, the E74A
mRNA is unique in that it contains a very long and complex $5^{\prime}$ untranslated leader sequence, 1891 nucleotides in length with 17 AUG triplets upstream from the long open reading frame that encodes the $E 74 \mathrm{~A}$ protein. The $E 74 B$ start sites are located $40 \mathrm{~kb}$ downstream from the $E 74 A$ promoter within the fifth intron of the $E 74 A$ unit and direct the synthesis of 4.8 and $5.1 \mathrm{~kb}$ mRNAs. These mRNAs contain shorter $5^{\prime}$ leaders than $E 74 A$, the longest being 793 nucleotides, with six short open reading frames upstream from the protein coding region. The nested arrangement of the E74 transcripts leads to the synthesis of two related proteins that have unique $\mathrm{N}$-terminal regions joined to a common C-terminal region (Burtis et al. 1990). Within the $\mathrm{C}$-terminal region is an 85 amino acid sequence designated the ETS-domain. This domain is shared by a family of proteins related to the ets oncoprotein and has been shown to function as a site-specific DNA-binding domain (Karim et al. 1990). In agreement with this sequence similarity, both $E 74 A$ and $E 74 B$ proteins bind to DNA sequences located approximately $11 \mathrm{~kb}$ upstream from the $E 74 B$ start sites. In addition, antibody stains of polytene chromosomes identified $E 74 A$ protein bound to both early and late ecdysoneinduced puffs, fulfilling a key prediction of the Ashburner model (Urness and Thummel, 1990). Thus, it seems likely that $E 74$ encodes two related DNAbinding proteins that recognize similar target sequences by virtue of their identical ETS-domains, but exert unique regulatory functions by virtue of their distinct N-terminal sequences.

Both the $E 74 A$ and $E 74 B$ promoters are directly activated by ecdysone and repressed by ecdysoneinduced proteins, providing further support for the Ashburner model. The lengths of the $E 74 A$ and $E 74 B$ transcription units have been shown to function as timers that delay by 60 and $20 \mathrm{~min}$, respectively, the appearance of the mature mRNAs in the cytoplasm. The timing of $E 74 A$ and $E 74 B$ transcription is further regulated by the different ecdysone concentrations required for their induction and repression (Thummel et al. 1990; Karim and Thummel, 1991). In support of the tissue coordination model, $E 74 A$ and $E 74 B$ are both transcribed in response to the major pulses of ecdysone during development. Further support is derived from the ecdysone-induction of $E 74 A$ and $E 74 B$ mRNA in cultured larval and imaginal tissues isolated from latethird instar larvae (Karim and Thummel, 1991).

Here we extend our characterization of E74A regulation by determining the spatial and temporal distribution of $E 74 A$ RNA and protein expression at the onset of metamorphosis. E74A is expressed in all late-third instar tissues examined, suggesting that it does not perform a tissue-specific regulatory function. $E 74 A$ RNA can be initially detected as nascent transcripts on the larval polytene chromosomes. With a few exceptions, nascent $E 74 A$ RNA can no longer be detected in the polytene nuclei of white prepupae, when the 74EF puff has regressed in the salivary glands. The levels of $E 74 A$ RNA decline in most tissues at puparium formation, with the exception of the gut, 
peripodial membranes of the imaginal discs, and proliferation centers of the brain, where relatively high levels of $E 74 A$ RNA persist in $1.5 \mathrm{~h}$ prepupae. The distribution of nuclear $E 74 A$ protein correlates with the $E 74 A$ RNA distribution with one exception: we find no evidence for $E 74 A$ protein in the proliferation centers of the brain. Studies of the timing of $E 74 A$ expression revealed that the broad $8-10 \mathrm{~h}$ expression of $E 74 A$ mRNA at the end of larval development is refined into a $5-7 \mathrm{~h}$ burst of $E 74 A$ protein, with the peaks offset by $\sim 2 \mathrm{~h}$. This delay in E74A protein accumulation is not evident $10 \mathrm{~h}$ later, in response to the next pulse of ecdysone, suggesting that it may be of regulatory significance and may contribute toward the timing of subsequent steps in the regulatory hierarchy.

\section{Materials and methods}

\section{Developmental staging of animals}

Larvae were grown on food containing $0.05 \%$ bromophenol blue (Sigma). As the larvae begin wandering the blue dye gradually clears from their intestine indicating the time since the cessation of feeding (Maroni and Stamey, 1983). This technique can be used to stage late-third instar larvae with an error of approximately $2-3 \mathrm{~h}$ at $25^{\circ} \mathrm{C}$ (L. B. and A. Andres, unpublished results). Larvae whose guts were completely blue were greater than $12 \mathrm{~h}$ away from puparium formation; these we designate as early wandering larvae. Larvae whose guts were cleared of dye were $\sim 3 \mathrm{~h}$ from puparium formation $( \pm 1.8 \mathrm{~h})$; these we designate as late wandering larvae. Prepupae were synchronized at the white prepupal stage $(0 \mathrm{~h})$ and allowed to develop on moistened filter paper at $25^{\circ} \mathrm{C}$ for the desired time. This staging is highly reproducible since the prepupae begin to tan approximately $15-20 \mathrm{~min}$ after pupariation.

\section{In situ hybridization}

Stationary late-third instar larvae, white prepupae, and $1.5 \mathrm{~h}$ prepupae were frozen, sectioned with a cryostat $(8 \mu \mathrm{m}$ sections), and mounted on subbed slides as described (Hafen and Levine, 1986). High specific-activity ${ }^{35}$ S-labeled RNA probes were prepared by in vitro transcription of a cloned $E 74 A$ cDNA containing the first three exons. This probe is specific for $E 74 A$ transcripts and will not cross-react with $E 74 B$. Probe synthesis and in situ hybridization were performed essentially as described by Ingham et al. (1985), following a protocol provided by $\mathrm{C}$. Rushlow and M. Levine. We did not acetylate and pronase digest the sections before hybridization. After coating with film emulsion, the slides were exposed for 2-3 weeks.

In situ hybridization to RNA in intact organs was performed according to Mlodzik et al. (1990), with minor modifications. The first fixation was supplemented with $0.1 \%$ deoxycholate. Larval and prepupal organs were dissected in a 9-well Corning dish and all subsequent incubations were done in such a dish placed on a rotating platform. The probe for whole-mount in situ hybridization was made by digoxygenin labeling an antisense oligonucleotide from nucleotides no. 409-461 of the E74A cDNA (Burtis et al. 1990). The labeling reaction consisted of $1.5 \mathrm{~mm} \mathrm{CoCl}, 10 \mu \mathrm{M}$ dATP, $200 \mu \mathrm{M}$ digoxigenin-dUTP (Boehringer-Mannheim), $1 \mu \mathrm{M}$ E74A oligonucleotide, and 75 units terminal transferase (BoehringerMannheim). The reaction was incubated at $37^{\circ} \mathrm{C}$ for $20 \mathrm{~min}$ after which the labelled oligonucleotide was ethanol precipitated and resuspended in $40 \mu \mathrm{l} \mathrm{TE}$. Approximately $5 \mu \mathrm{l}$ of probe was used for each hybridization $(5 \mu \mathrm{l}$ probe in $\sim 95 \mu \mathrm{l}$ hybridization solution). Anti-digoxigenin antibodies (Boehringer-Mannheim) were preabsorbed to dissected and fixed larval organs. Alkaline phosphatase-conjugated antibodies were used at a 1:200 final dilution in PBT. Incubation with the antibody ranged from $3 \mathrm{~h}$ at room temperature to overnight at $4^{\circ} \mathrm{C}$. The alkaline phosphatase stained organs were mounted in Mowiol mounting solution (Harlow and Lane, 1988) and photographed with Kodacolor Gold 200 film on a Zeiss Axiophot photomicroscope equipped with differential interference contrast.

For confocal microscopy, E74A RNA was identified with an anti-digoxigenin-fluorescein antibody (Boehringer-Mannheim, preabsorbed and then diluted 1:10 in PBT) and the chromosomes were detected with a monoclonal antibody supernatant (8C5: a gift from S. Benzer) which was added at a 1:4 dilution with the anti-digoxigenin antibody. This was followed by three $10 \mathrm{~min}$ washes and a $1.5 \mathrm{~h}$ incubation with a goat anti-mouse Texas Red antibody (Jackson ImmunoResearch Laboratories) diluted 1:100 in PBT. After further washing, the organs were mounted in Mowiol mounting solution which was supplemented with $2 \mathrm{mg} \mathrm{ml}^{-1}$ phenylenediamine (Sigma). The fluorescent stains were imaged on a BioRad confocal laser scanning microscope (MRC 600). Images were generated from Kalman averaging of $\sim 20$ scans. Each specimen was scanned with dual detector channels for fluorescein and Texas Red emission wavelengths. The dual images were merged with the 'alternate pixel' command.

\section{$R N A$ isolation and northern blots}

RNA was isolated from 30-50 staged larvae or prepupae placed in a $7 \mathrm{ml}$ homogenizer with $200 \mu$ l RNA lysis buffer $(100 \mathrm{~mm}$ Tris $-\mathrm{HCl} \mathrm{pH} 7.8,0.3 \mathrm{~m}$ sodium acetate, $20 \mathrm{~mm}$ EDTA, $1 \%$ sarkosyl) and homogenized with five strokes of a B pestle. Immediately, $200 \mu \mathrm{l}$ phenol was added followed by five more strokes with the $\mathrm{B}$ pestle. The mixture was centrifuged and the aqueous portion was extracted with phenol two more times. Then, $400 \mu \mathrm{l}$ ethanol was added and allowed to sit for $5 \mathrm{~min}$ at room temperature. The RNA was pelleted, resuspended in $30-50 \mu \mathrm{l}$ water, and stored at $-80^{\circ} \mathrm{C}$.

Approximately $20 \mu \mathrm{g}$ of total RNA from each time point was electrophoresed on $1 \%$ formaldehyde agarose gels and blotted onto Nytran. Northern blot hybridizations were performed as described (Thummel et al. 1990). Blots were probed with a ${ }^{32} \mathrm{P}$-labelled single-stranded cDNA probe, derived from the first 3 exons of $E 74 A$, synthesized as described (Burtis et al. 1990).

\section{Antibodies}

An $E 74 A / \beta$-galactosidase fusion protein was constructed by inserting the entire E74A ORF into pWR-590-1 (Guo et al. 1984). The E74A C-terminal coding region was then removed as a Pst I restriction fragment. The protein encoded by this plasmid contains most of $\beta$-galactosidase fused to 111 $\mathrm{N}$-terminal amino acids of $E 74 A$, including 19 amino acids of sequence common to $E 74 A$ and $E 74 B$. The fusion protein was expressed in E. coli DH5 and purified from inclusion bodies essentially as described (Rio et al. 1986), except that we used $25 \mathrm{~mm}$ or $250 \mathrm{~mm}$ Hepes pH 7.5 in place of $50 \mathrm{~mm}$ and $500 \mathrm{~mm}$ Tris- $\mathrm{HCl}$. After urea extraction, the protein was dialyzed overnight in $0.1 \mathrm{~m}$ Hepes $\mathrm{pH} 8$ and centrifuged to remove insoluble material. The fusion protein was further purified by precipitation with $30 \%$ ammonium sulfate, after which the 
mixture was centrifuged at $10000 \mathrm{revs} \mathrm{min}^{-1}$ for $10 \mathrm{~min}$. The pellet was resuspended in $10 \mathrm{ml}$ of running buffer $(10 \mathrm{~mm}$ Tris pH 7.5, $1 \mathrm{~mm}$ EDTA, $20 \mathrm{~mm} \mathrm{NaCl}$ ) and centrifuged again to remove insoluble material. This supernatant was then loaded onto a $1.5 \times 50 \mathrm{~cm}$ BioRad Econo column containing $75 \mathrm{ml}$ of Sephacryl S-200 (Pharmacia) in running buffer. Eighty $2 \mathrm{ml}$ fractions were collected and the fusion protein was recovered in fractions no. 14-19 which were pooled and used for immunization. Approximately $100 \mu \mathrm{g}$ of $\sim 90 \%$ pure protein was obtained from $500 \mathrm{ml}$ of bacterial culture.

The purified E74A fusion protein was injected subcutaneously into rabbits at the Pocono Rabbit Farm. Antiserum was centrifuged and the supernatant was passed over two columns to affinity-purify anti-E74A antibodies. The first column removed contaminating anti- $\beta$-galactosidase and antibacterial antibodies and the second column selected for antibodies directed against $E 74 \mathrm{~A}$ protein. The first column was prepared by coupling proteins from an extract of bacteria carrying pWR-590 (Guo et al. 1984) to Affigel 15 (BioRad). The extract was prepared as described above for the fusion protein, excluding the ammonium sulfate precipitation and sizing column. The $E 74 A$ affinity column was prepared by coupling proteins from an extract of bacteria over-expressing $E 74 A$ protein (pET-E74A, Urness and Thummel, 1990) to Affigel 15. This column was washed with PBS and PBS, $0.1 \%$ Tween-20 until the effluent $\mathrm{OD}_{280}=0$. The anti-E74A antibodies were eluted from the second column with $4 \mathrm{M}$ guanidine $-\mathrm{HCl}, 10 \mathrm{~mm}$ Tris $-\mathrm{HCl} \mathrm{pH} 8$. Seven $1 \mathrm{ml}$ fractions were collected and dialyzed in PBS pH 7.5. These fractions were tested for activity by western blot analysis using crude extracts from bacteria containing the pWR-590 plasmid and pET-E74A which expresses full-length E74A protein (Urness and Thummel, 1990). The fifth and sixth fractions were the most specific and were used for these studies.

\section{Protein extracts and western blotting}

Protein extracts were prepared from 30-50 staged larvae or prepupae placed into liquid nitrogen and ground to a powder with a ceramic pestle. The powder was resuspended in $\sim 2 \mathrm{ml}$ $50 \%(\mathrm{v} / \mathrm{v})$ acetonitrile, $50 \% 0.3 \mathrm{~m}$ ammonium carbonate pH 9.6 (Ollo and Maniatis, 1987) with $10 \mathrm{~mm}$ EDTA, $10 \mathrm{~mm}$ EGTA, $1.4 \mu \mathrm{g} \mathrm{ml}^{-1}$ pepstatin (Boehringer-Mannheim), $1 \mu \mathrm{g} \mathrm{ml}^{-1}$ leupeptin (Boehringer-Mannheim), $400 \mu \mathrm{g} \mathrm{ml}^{-1}$ PMSF (Sigma). This suspension was lyophilyzed and the resulting powder was resuspended in $600 \mu \mathrm{l}$ SDS loading buffer. The extracts were boiled for $5 \mathrm{~min}$ and centrifuged prior to electrophoresis. Extracts from dissected tissues were prepared by disrupting the organs in hot SDS loading buffer. The extracts were vortexed repeatedly and boiled for $5 \mathrm{~min}$ before loading.

Protein extracts were electrophoresed on $6 \%$ SDSpolyacrylamide gels essentially as described (Sambrook et al. 1989) and transferred to nitrocellulose (Fig. 4A) or Biodyne A membranes (Fig. 4B and 5) with a Milliblot-SDE (Millipore) at $2.5 \mathrm{~mA}$ per $\mathrm{cm}$ of membrane for $45 \mathrm{~min}$. All detection steps were performed at room temperature except incubation with the primary antibody. The membranes were blocked in milk solution $(5 \%$ dry milk, $500 \mathrm{~mm} \mathrm{NaCl}, 20 \mathrm{~mm}$ Tris- $\mathrm{HCl}$ $\mathrm{pH} 7.5)$ for $1 \mathrm{~h}$. Affinity purified anti-E74A antibody was diluted 1:1000 in milk solution and incubated with the membranes overnight at $4^{\circ} \mathrm{C}$. Blots were rinsed three times for $10 \mathrm{~min}$ with milk solution before adding the goat antirabbit alkaline phosphatase antibody (Jackson ImmunoResearch Laboratories) which was used at a 1:10000 dilution for $2-6 \mathrm{~h}$. The blots were rinsed once with milk solution, twice for $5 \mathrm{~min}$ with $20 \mathrm{~mm}$ Tris- $\mathrm{HCl} \mathrm{pH} 9.6,500 \mathrm{~mm} \mathrm{NaCl}, 0.05 \%$
Tween-20, and once for $5 \mathrm{~min}$ with $20 \mathrm{~mm}$ Tris- $\mathrm{HCl} \mathrm{pH} 9.6$, $500 \mathrm{~mm} \mathrm{NaCl}$.

For colorimetric alkaline phosphatase detection (Fig. 4A), the blot was incubated for $10 \mathrm{~min}$ to overnight in $100 \mathrm{~mm}$ $\mathrm{NaHCO}_{3}, 1 \mathrm{~mm} \mathrm{MgCl}$ pH 9.6 with $0.3 \mathrm{mg} \mathrm{ml}^{-1}$ nitro-blue tetrazolium (Sigma) and $0.15 \mathrm{mg} \mathrm{ml}^{-1}$ bromo-chloro-indolyl phosphate (Sigma). For chemiluminescent detection, the blot was preincubated for $5 \mathrm{~min}$ in Assay Buffer $(100 \mathrm{~mm}$ diethanolamine (Sigma), $1 \mathrm{~mm} \mathrm{MgCl} 2 \mathrm{pH} 9.8$ ), then incubated in Tropix AMPPD substrate $\left(70 \mu \mathrm{g} \mathrm{ml}^{-1}\right.$ in Assay Buffer) in the dark at $37^{\circ} \mathrm{C}$ for $15 \mathrm{~min}$. The blot was washed very briefly in Assay Buffer and exposed on Kodak X-Omat X-ray film for $10 \mathrm{~min}$ to overnight at $37^{\circ} \mathrm{C}$. Chemiluminescence was approximately five times more sensitive than the chromogenic substrate for alkaline phosphatase. However, this added sensitivity was coupled to an increase in detection of background bands due, at least in part, to the use of a nylon membrane instead of nitrocellulose. The nylon membrane proved essential for the increased sensitivity.

\section{Antibody staining of whole organs}

The protocol that we used to stain organs is modified from Carroll and Whyte (1989). Larvae or prepupae were dissected in PBS in a 9-well Corning dish in which all subsequent steps were performed. All steps except the anti-E74A antibody incubations were done at room temperature. The organs were fixed for $20 \mathrm{~min}$ in $4 \%$ formaldehyde, $100 \mathrm{~mm}$ Pipes $\mathrm{pH} 6.9$, $1 \mathrm{~mm}$ EGTA, $2 \mathrm{~mm} \mathrm{MgSO}_{4}, 0.5 \%$ Triton X-100. They were then washed twice with TN3 [50 mм Tris- $\mathrm{HCl} \mathrm{pH} \mathrm{7.0,} 150 \mathrm{~mm}$ $\mathrm{NaCl}, 0.5 \%$ Triton X-100, $2 \%$ normal goat serum (Sigma)]. Blocking was done for $1 \mathrm{~h}$ in TN3 that contained $10 \%$ normal goat serum. Anti-E74A antibody was diluted 100 -fold in TN3 and incubated with the organs overnight at $4^{\circ} \mathrm{C}$. The organs were then washed three times for $30 \mathrm{~min}$ in TN3. Goat antirabbit horseradish peroxidase-conjugated secondary antibodies (Vector Labs) were diluted 1:400 in TN3 and incubated with the organs for $2 \mathrm{~h}$. The organs were washed three times for $30 \mathrm{~min}$ with TN3 and then once with $100 \mathrm{~mm}$ Tris- $\mathrm{HCl}$ $\mathrm{pH}$ 7.0. Peroxidase activity was detected with $0.5 \mathrm{mg} \mathrm{m}^{-1}$ diaminobenzidine (Sigma), $90 \mathrm{~mm}$ Tris- $\mathrm{HCl} \mathrm{pH} 7.0,0.03 \%$ $\mathrm{CoCl}_{2}$, and $0.03 \% \mathrm{H}_{2} \mathrm{O}_{2}$. The reaction was allowed to proceed for 3-10 min, after which the organs were washed

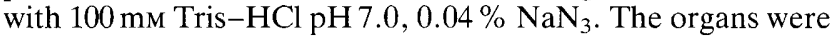
mounted on slides in Mowiol mounting solution and photographed as described for the alkaline phosphatase in situ hybridizations.

\section{Antibody staining of frozen sections}

Sections were prepared as described for the in situ hybridization. All subsequent steps were done at room temperature. Tissue sections were fixed for $30 \mathrm{~min}$ in $2 \%$ formaldehyde, $100 \mathrm{~mm}$ Pipes pH 6.9, 1 mм EGTA, $2 \mathrm{~mm} \mathrm{MgSO}_{4}$. The slides were rinsed in TBS and washed in TBS for $5 \mathrm{~min}$. The sections were blocked with TBS, $2 \%$ normal goat serum for $15 \mathrm{~min}$ before an overnight incubation with anti-E74A antibodies diluted $1: 10$ in TBS, $2 \%$ normal goat serum, $0.05 \%$ NP- 40 . The slides were rinsed and washed twice with TBS for $5 \mathrm{~min}$. Goat anti-rabbit horseradish peroxidase-conjugated secondary antibody was diluted $1: 100$ in TBS, $2 \%$ normal goat serum, $0.05 \%$ NP- 40 and incubated with the tissues for $2 \mathrm{~h}$. The slides were rinsed and washed twice with TBS, then soaked in the substrate reaction mixture described above for approximately $5 \mathrm{~min}$. Slides were washed briefly with TBS, then water. Coverslips were placed on the slides with Mowiol mounting solution and the tissues were photographed as described for the alkaline phosphatase in situ hybridizations 


\section{Results}

Tissue-specific patterns of E74A transcription at the onset of metamorphosis

We previously showed that the rising ecdysone titer in late-third instar larvae induces $E 74 A$ transcription in a variety of larval and imaginal tissues (Thummel et al. $1990)$. Here we extend this analysis to early prepupal development, after the ecdysone titer and E74A RNA levels have peaked and are decreasing. Frozen sections of stationary late-third instar larvae (Fig. 1A,B), newly formed white prepupae (Fig. 1C,D), and $1.5 \mathrm{~h}$ prepupae (Fig. 1E,F) were hybridized with an ${ }^{35}$ S-labelled RNA probe derived from the first three exons of the $E 74 A$ mRNA. This probe is specific for $E 74 A$ and will not cross-react with the $E 74 B$ RNAs. No specific hybridization was observed with an identical $E 74 A$ probe in the sense orientation. Probes of both orientations bound non-specificially to chitinous structures such as the tracheae, cuticle and pharyngeal bars (Fig. 1, data not shown).

In agreement with our previous observations (Thummel et al. 1990), E74A RNA is abundantly expressed in most, if not all, tissues of late-third instar larvae (Fig. 1A). In larval tissues E74A RNA is concentrated over the large polytene nuclei. This nuclear localization is most obvious in the salivary gland ( $\mathrm{S}$, Fig. 1A), although it can also be detected in the polytene nuclei of fat bodies, intestine, proventriculus, epidermis and muscle (Fig. 1A,B). The relative abundance of $E 74 A$ RNA within the nucleus probably reflects a large number of nascent transcripts associated with the $60 \mathrm{~kb}$ $E 74 A$ transcription unit. This possibility is supported by the discrete subnuclear localization of the E74A RNA within what appears to be the $74 \mathrm{EF}$ puff, as discussed below.

E74A RNA is also expressed in imaginal tissues. Since the diploid nuclei in these tissues are relatively small, detection of nuclear E74A RNA is not expected nor discernible. $E 74 A$ RNA is present in eye-antennal, wing, and leg imaginal discs (D and W, Fig. 1A) as well as genital and haltere discs (data not shown). Expression in the imaginal discs appears to be more intense around their perimeter in what appears to be the peripodial membrane. In the larval brain $E 74 A$ RNA is preferentially expressed in specific cell types, including the glial cells surrounding the neuropil $(\mathrm{N}$, Fig. 1A) and the proliferation centers (arrow, Fig. 1A; White and Kankel, 1978). Little or no E74A RNA was detected in the other cells of the brain cortex (B, Fig. 1A).

The overall levels of E74A RNA decline during the transition from late-third instar larva to white prepupa (Fig. 1C,D), in agreement with the levels of E74A mRNA detected by northern blot hybridization (Fig. 4). Although some cytoplasmic E74A RNA can be detected in the salivary glands (S, Fig. 1C), the intense nuclear signal is no longer detectable, paralleling the regression of the 74EF puff by puparium formation (Ashburner, 1967). Relatively high levels of $E 74 A$ RNA remain in the proventriculus and intestine, as well as lower levels in the fat body (Fig. 1C,D). As with the salivary glands, these larval tissues no longer show the distinct nuclear localization of $E 74 A$ RNA that was seen several hours earlier. $E 74 A$ RNA persists in the brain and imaginal discs (Fig. 1C,D), with the highest concentration in the proliferation centers of the brain.

The levels of $E 74 A$ RNA decline further in $1.5 \mathrm{~h}$ prepupae, in agreement with the $6 \mathrm{~kb} E 74 A$ mRNA detected on northern blots (Fig. 4). Figs $1 \mathrm{E}$ and $1 \mathrm{~F}$ have been overexposed to emphasize the details of the E74A expression pattern. The overall distribution resembles that seen in white prepupae. Surprisingly, however, the levels of $E 74 A$ RNA remain high in the proliferation centers of the brain and the imaginal discs. Furthermore, the concentration of E74A RNA around the perimeter of the imaginal discs is more evident $(D$, Fig. 1E,F).

Thus, the pattern of $E 74 A$ RNA changes in a tissuespecific manner during the larval-prepupal transition. Ecdysone induces $E 74 A$ expression in most, if not all, late-third instar tissues. This pattern is resolved during puparium formation, with the highest levels of $E 74 A$ RNA remaining in the gut, proliferation centers of the brain, and in what appears to be the peripodial membranes of the imaginal discs.

\section{Temporal patterns of subnuclear E74A RNA accumulation}

The localization of $E 74 A$ RNA within the polytene nuclei of late larval tissues suggested that we might be detecting the RNA at its site of synthesis in the polytene chromosomes. This was supported by occasional in situ hybridizations that showed a more discrete cluster of silver grains within the polytene nuclei (Fig. 4B in Thummel et al. 1990). In order to localize more precisely E74A RNA in polytene nuclei, we performed non-radioactive in situ hybridizations to whole-mount organs. Salivary glands were isolated from early wandering larvae (earlier than $-12 \mathrm{~h}$ ), late wandering larvae $(-3 \mathrm{~h})$, white prepupae and $2 \mathrm{~h}$ prepupae. Whole-mount in situ hybridizations were performed following a modification of the procedure reported by Tautz and Pfeifle (1989; Mlodzik et al. 1990). An antisense oligonucleotide derived from the first exon of $E 74 A$ was $3^{\prime}$ tailed with digoxigenin-dUTP using terminal transferase. Following hybridization with $E 74 A$ RNA, the oligonucleotide was detected with an anti-digoxigenin antibody that was conjugated to either alkaline phosphatase, for light microscopy (Fig. 2) or fluorescein, for confocal laser scanning microscopy (Fig. 3). An oligonucleotide in the sense orientation was used as a negative control to detect potential hybridization to DNA. Although these two probes were equivalent in their detection of $E 74 A$ DNA by slot-blot hybridization, no signal could be detected in larval tissues using the sense orientation probe (data not shown).

Fig. 2A shows a time course of E74A RNA localization in larval and prepupal salivary glands. The relative levels of nuclear $E 74 A$ RNA detected by this 
procedure confirm the results of our radioactive in situ hybridizations; furthermore, the level of resolution is vastly improved by staining intact organs with the enzymatic detection system. No E74A RNA can be detected in early wandering larval salivary glands. $E 74 A$ RNA is present in the nuclei of late wandering larval salivary glands, within a highly localized region that appears as a linear or arc-shaped band (Fig. 2A, $3 \mathrm{~A})$. In white prepupae and $2 \mathrm{~h}$ prepupae, nuclear $E 74 A$ RNA can no longer be detected, even with prolonged times of color development. Control prepupal salivary glands, processed without the oligonucleotide probe, developed background staining in the cytoplasm. This background combined with the diffuseness of cytoplasmic $E 74 A$ mRNA, relative to the high concentration localized in the nucleus, made it difficult to assess the levels of cytoplasmic E74A RNA using this technique.

The time course of expression of E74A nuclear RNA was determined for other late wandering larval tissues, including the mouth part muscles, ring gland, trachea, Malpighian tubules, proventriculus, gastric caecae, and mid-intestine (Fig. 2B). Most of these tissues showed the same expression pattern as that seen in salivary glands. No E74A RNA can be detected in tissues isolated from early wandering larvae (data not shown). Nuclear E74A RNA is present in all late wandering larval tissues examined and in most tissues the nuclear signal is no longer detectable in white prepupae (Fig. 2B). However, nuclear $E 74 A$ expression persisted in some tissues. The mouth part muscles, ring gland and Malpighian tubules have lower but clearly detectable levels of nuclear $E 74 A$ RNA in white prepupae (arrows, Fig. 2B). This suggests that E74A transcription is not repressed at the same time in all larval tissues.

\section{Nuclear E74A RNA appears to be localized within the polytene chromosomes}

To generate a higher resolution image of E74A RNA in polytene nuclei, we used fluorescein-conjugated antidigoxigenin antibodies and confocal laser scanning microscopy. In so doing, we hoped to determine the shape and dimensions of the $E 74 A$ subnuclear RNA as well as whether it might originate from the 74EF puff. As a counterstain, the polytene chromosomes were visualized with a mouse monoclonal antibody and Texas Red-conjugated goat anti-mouse secondary antibody. By using the confocal laser scanning microscope we could visualize the E74A RNA and polytene chromosomes separately (Fig. 3C) or merge the images (Fig. 3A,B). We could also determine the threedimensional shape of the subnuclear RNA signal by optical sectioning. We focused our analysis on salivary gland nuclei because of their well-characterized chromosome morphology and the reproducibly strong signal from $E 74 A$ RNA. Data from other larval tissues (ring gland, mid-intestine, gastric caecae and proventriculus) resemble that seen with salivary glands (data not shown).

$E 74 A$ RNA forms a tight band within one of the chromosome arms (Fig. 3). In several images two adjacent decondensed regions, separated by a condensed region, can be clearly visualized in the polytene chromosomes (arrows, Fig. 3C). This pattern is very similar to that of the neighboring early ecdysoneinducible puffs at positions 74EF and 75B (Ashburner, 1967). Nuclear E74A RNA co-localizes with one of these two decondensed regions (Fig. 3B), which we presume to be the 74EF puff. Further evidence that we are detecting nascent transcripts and not sequestered mature E74A mRNA was obtained by detecting the RNA with an oligonucleotide probe directed against sequences within the first $E 74 A$ intron. The signal with the intron probe is less intense, but the size and shape of that signal are indistinguishable from that generated with the exon-specific probe (data not shown).

The band of $E 74 A$ RNA has sharp demarcations with no diffuse staining along its edges. In some salivary glands, we have seen nuclei that contain two separate, smaller bands. This is probably due to asynapsis which occurs rarely in salivary gland chromosomes (Walker and Ashburner, 1981). The three-dimensional shape of the $E 74 A$ RNA signal is not that of a perfectly circular, but rather elliptical disc. The E74A RNA signal (perpendicular to the centromere-telomere axis) ranges from 3.3 to $4.9 \mu \mathrm{m}$ in length, with an average length of $4.3 \pm 0.5 \mu \mathrm{m}(n=13)$. In 45 of 50 nuclei that were examined, the band of E74A RNA adjoins the edge of the nucleus (Fig. 3A).

\section{The peak of $\mathrm{E} 74 \mathrm{~A}$ protein accumulation lags behind that of E74A $m R N A$}

Our previous characterization of $E 74 A$ expression has been limited to transcription, either by northern blot hybridization (Thummel et al. 1990; Karim and Thummel, 1991) or in situ RNA analysis, as presented above. In order to compare these transcription patterns with those of $E 74 A$ protein, polyclonal antibodies were raised by immunizing rabbits with a purified $E 74 A / \beta$ galactosidase fusion protein. Anti-E74A antibodies were purified from the rabbit antiserum by sequential affinity chromatography steps: first, removal of anti- $\beta$ galactosidase antibodies and then selection for antibodies directed against E74A protein (see Materials and methods). The most highly purified fractions detected only $E 74 A$ protein in western blot analysis of total prepupal extracts when visualized by chromogenic detection of an alkaline phosphatase-conjugated secondary antibody (Fig. 4A).

In order to quantitate and compare $E 74 A \mathrm{mRNA}$ and protein levels, northern and western blots were prepared using RNA and protein isolated from staged intact animals. Groups of $60-100$ staged larvae or prepupae were collected and RNA was extracted from half of the population while the remainder were used to prepare protein extracts. Although a variety of conditions were used to avoid proteolysis, extraction with acetonitrile reproducibly yielded extracts that contained intact E74A protein (Ollo and Maniatis, 1987). Equivalent amounts of either RNA or protein were fractionated by gel electrophoresis and transferred to 
A

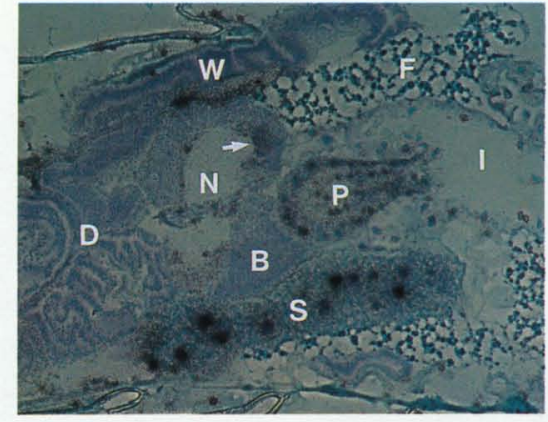

B

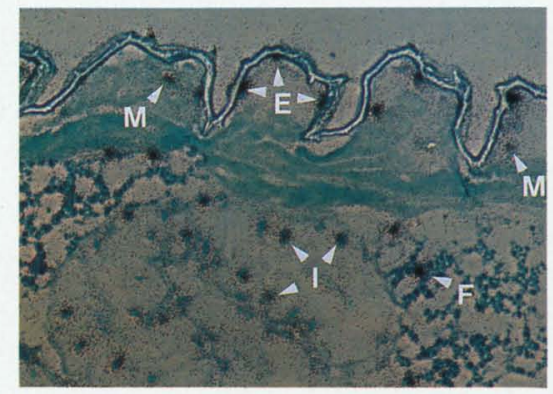

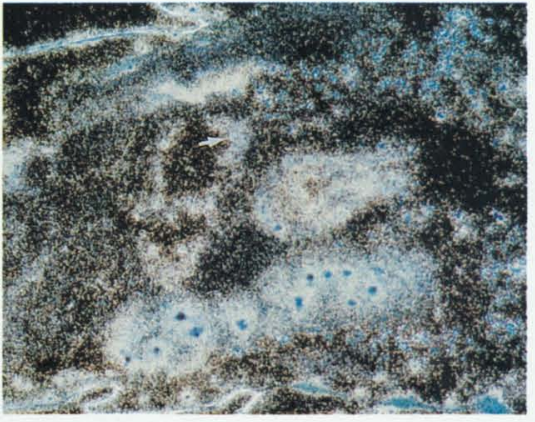

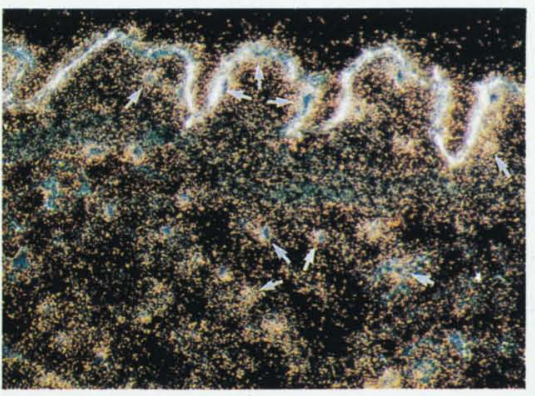

White prepupa

C

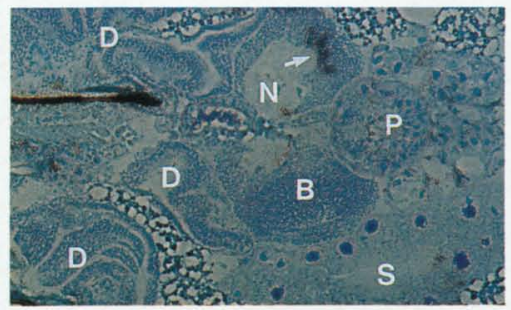

D

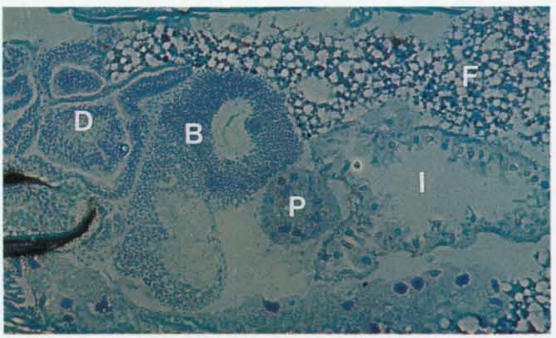

\section{5 h prepupa}

E

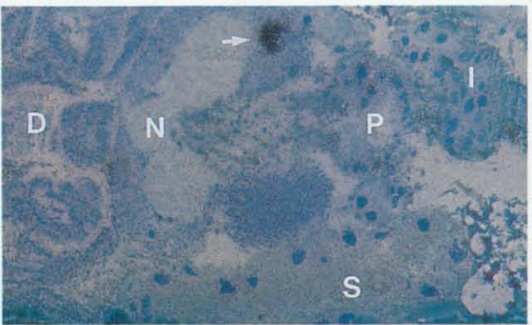

F

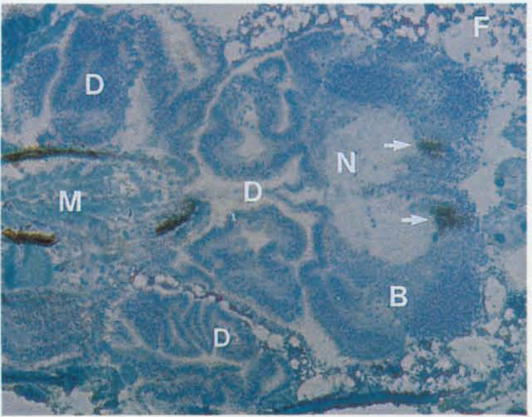

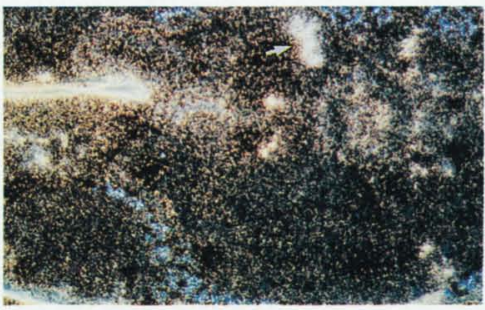
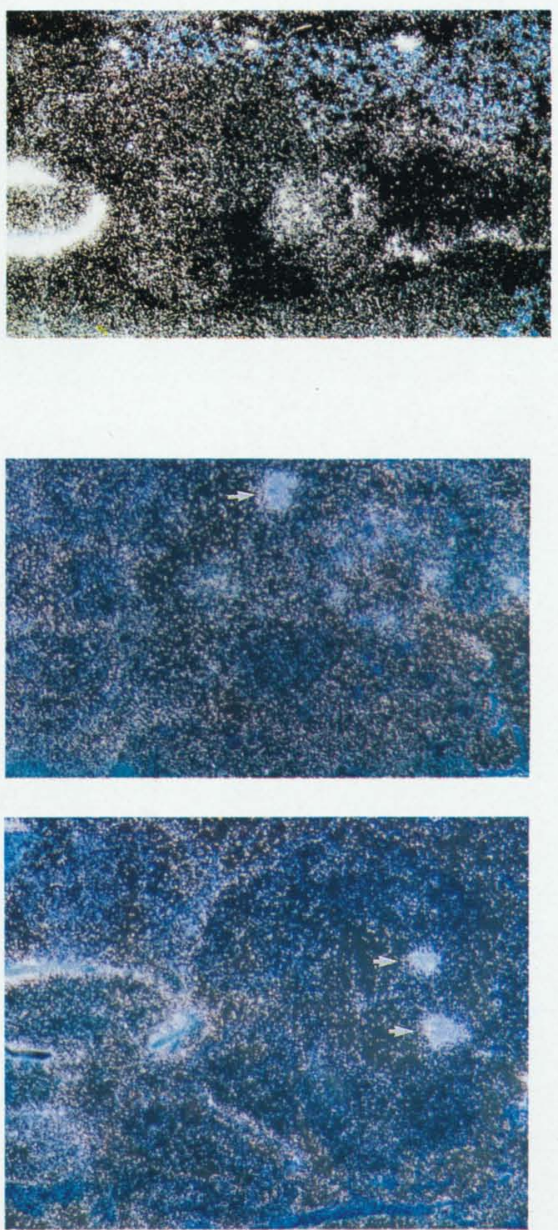

Fig. 1. Distribution of $E 74 A$ RNA in a stationary latethird instar larva (A,B), white prepupa $(C, D)$, and $1.5 \mathrm{~h}$ prepupa (E,F). Brightfield (left) and dark-field (right) photomicrographs show the distribution of E74A RNA in longitudinal cryostat sections. Anterior is to the left. Unlabeled arrows in $\mathrm{A}, \mathrm{C}, \mathrm{E}$ and $\mathrm{F}$ point to the proliferation centers in the brain. Arrowheads in B point to nuclear localization of $E 74 A$ RNA. Non-specific association of the radioactive probe with chitinous structures leads to intense artifactual signals over the cuticle $(A, B, F)$, pharyngeal bars (black structures in $\mathrm{C}, \mathrm{D}, \mathrm{F}$ ), and trachae [A along the lower edge of the wing disc (W); C - two regions in the central posterior portion of the brain adjoining the neuropil $(\mathrm{N})$, also below the pharyngeal bar; D - in the fat bodies (F)]. The emulsion in $\mathrm{E}$ and $\mathrm{F}$ was exposed somewhat longer than A-D to accentuate the pattern in the imaginal discs. $\mathrm{B}$, brain cortex; D, leg and eyeantennal imaginal discs; $\mathrm{E}$ epidermis; F, fat body; I, intestine; $\mathrm{M}$, muscle; $\mathrm{N}$, neuropil; $\mathrm{P}$, proventriculus; $\mathrm{S}$, salivary gland; $\mathrm{W}$, wing disc. 


\section{$-3 \mathrm{hr}$ larva}
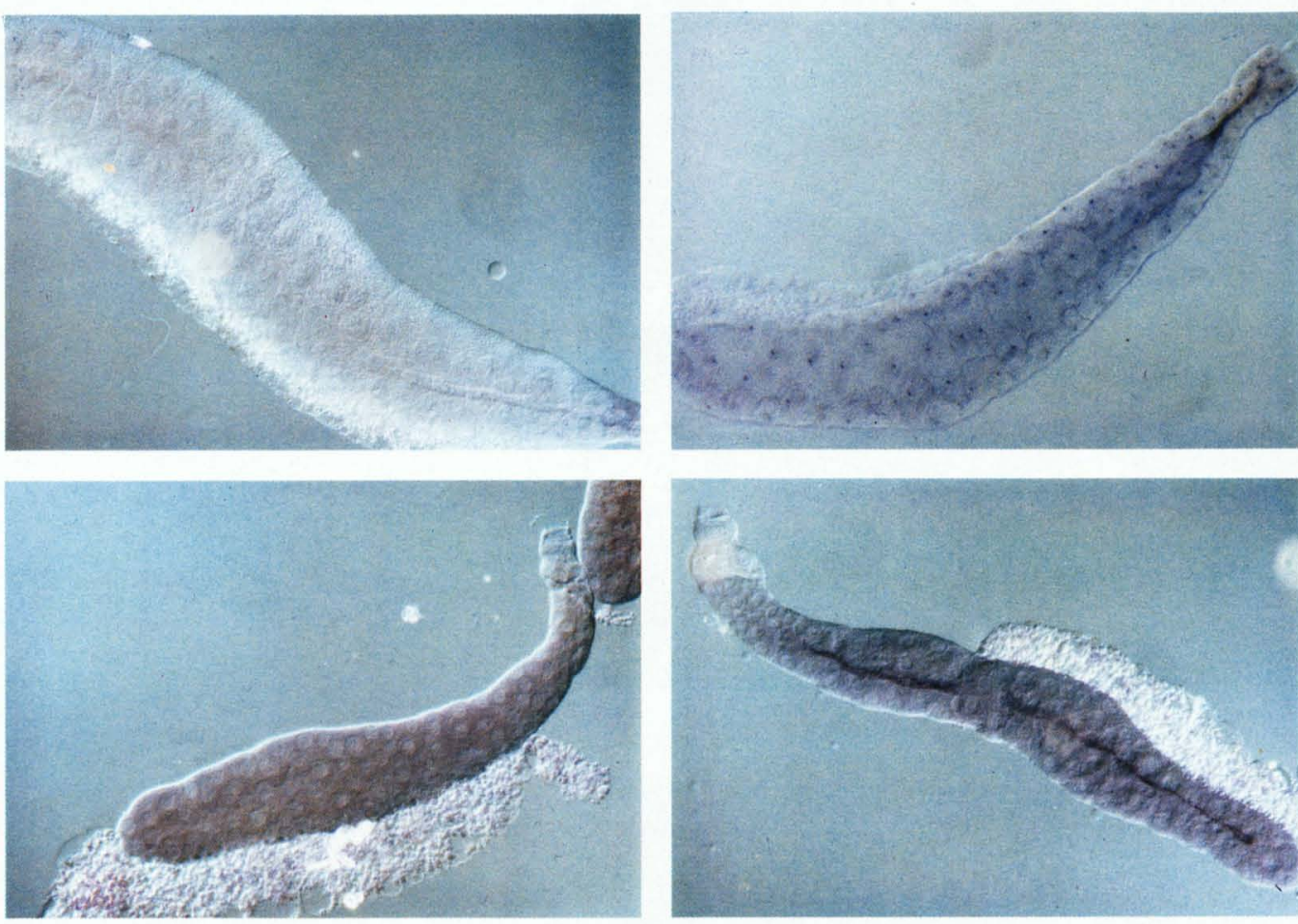

White prepupa

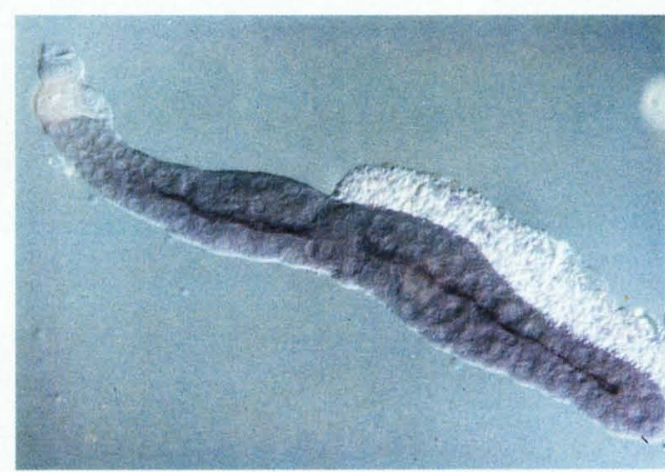

2 hr prepupa
B
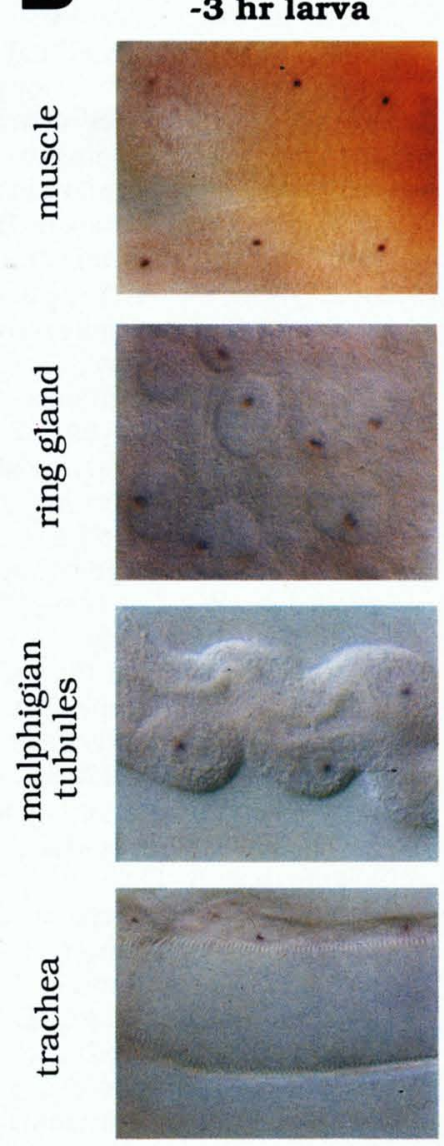

\section{White prepupa}
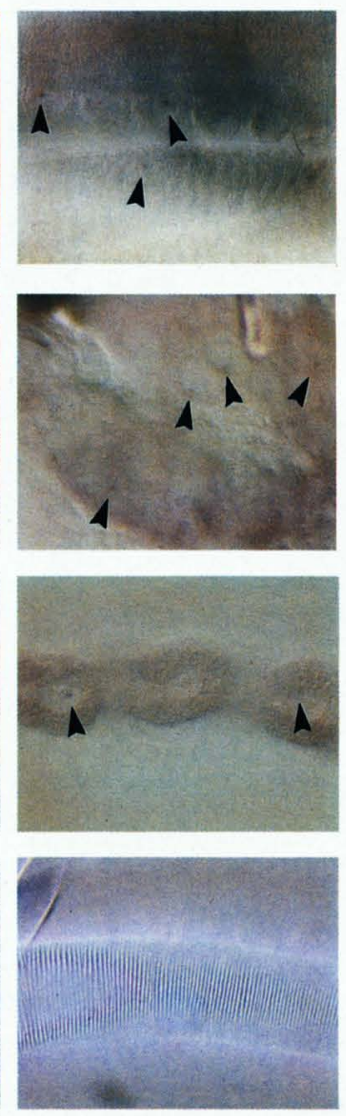

Fig. 2. Time course of subnuclear E74A RNA expression detected by in situ hybridization in intact organs. (A) Salivary glands isolated from a early wandering larva and late wandering larva $(-12$ and $-3 \mathrm{~h}$, respectively, see Materials and methods), a white prepupa, and $2 \mathrm{~h}$ prepupa show nuclear $E 74 \mathrm{~A}$ RNA only at the $-3 \mathrm{~h}$ timepoint. (B) Two time points $(-3 \mathrm{~h}$ larva and white prepupa) showing the decrease in levels of subnuclear $E 74 A$ RNA in other polytene larval tissues: mouth part muscles, ring gland, Malpighian tubules, trachea, proventriculus, gastric caecae and midintestine. E74A RNA is detected in the nuclei of these tissues isolated from a late wandering larva. Only in muscle, ring gland and Malpighian tubules can a low, but reproducible, level of subnuclear $E 74 A$ RNA be detected in white prepupae (arrows).

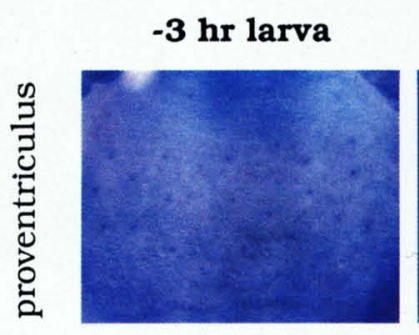

\section{White prepupa}
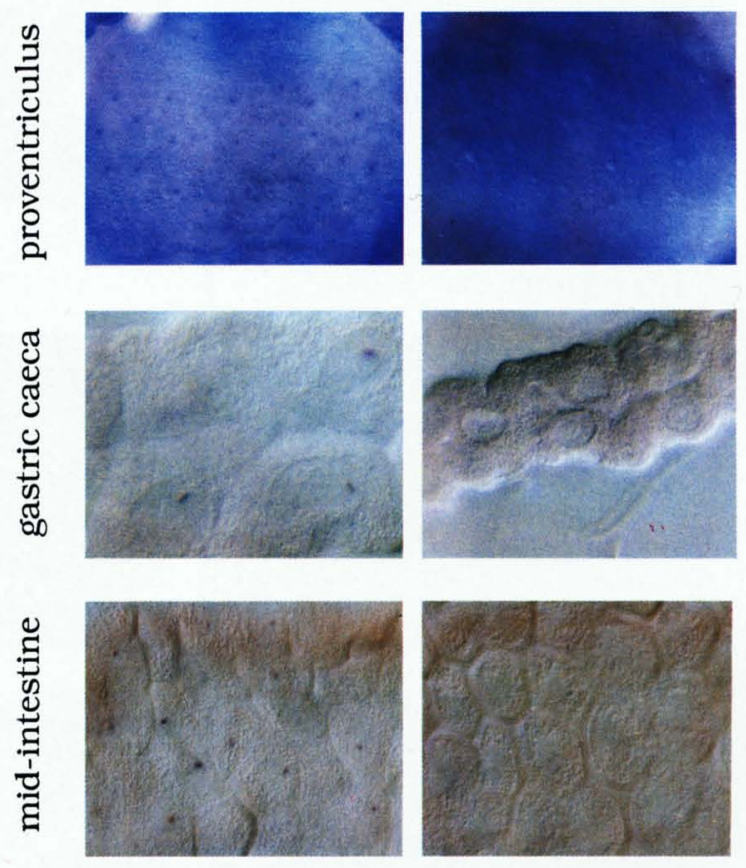

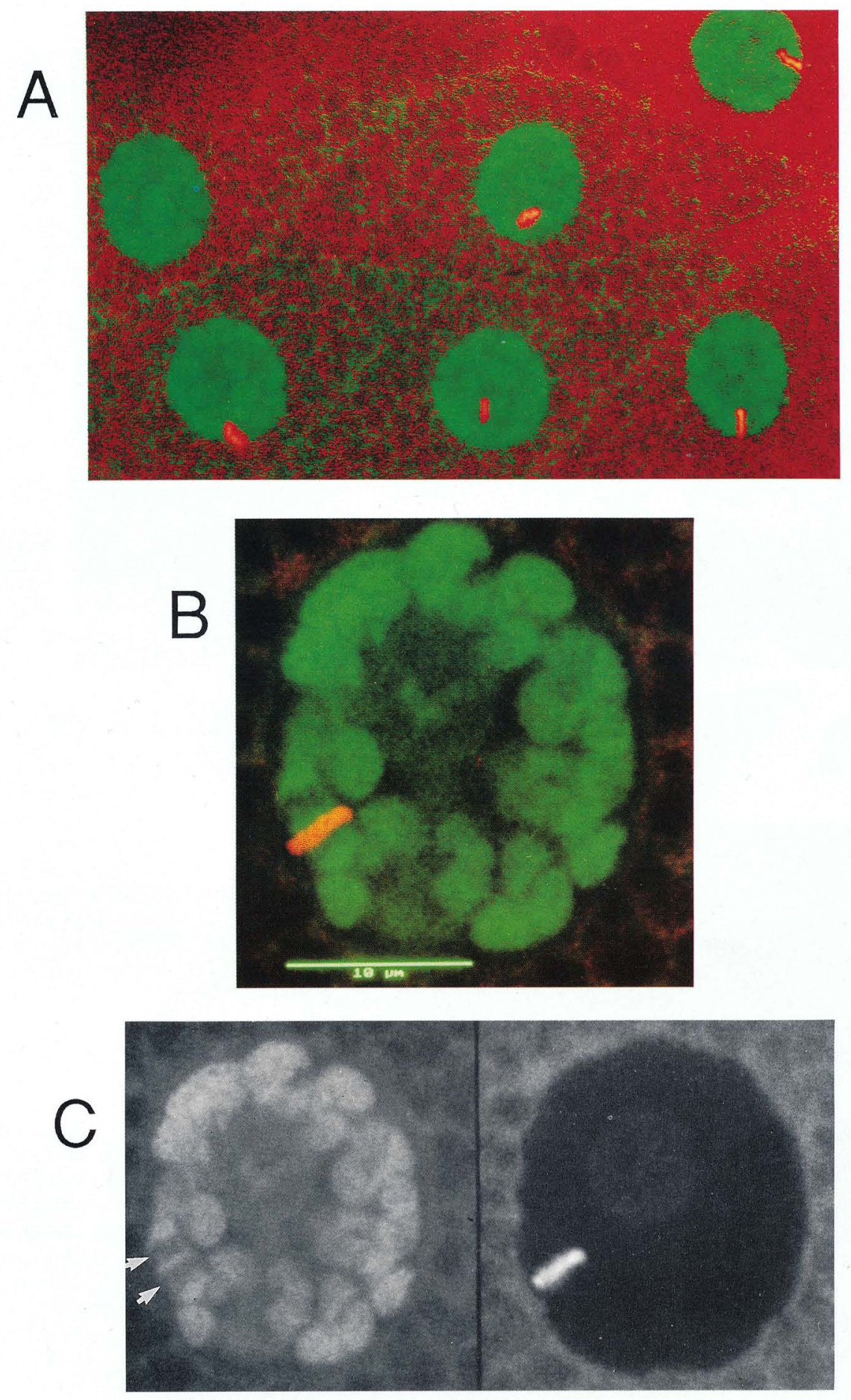

Fig. 3. Subnuclear localization of $E 74 A$ RNA in late wandering larval salivary gland cells as detected by in situ hybridization and confocal laser scanning microscopy. (A,B) E74A RNA is present on the polytene chromosomes (green) as a discrete band (red) that usually adjoins the edge of the nucleus. (C) Two adjacent decondensed regions in the polytene chromosomes (arrows) resemble the paired 74EF and 75B early ecdysoneinduced puffs. E74A RNA co-localizes with the lower of these two regions. An overlay of these images is shown in panel B. The bar represents $10 \mu \mathrm{m}$. 
A Hours relative to puparium formation

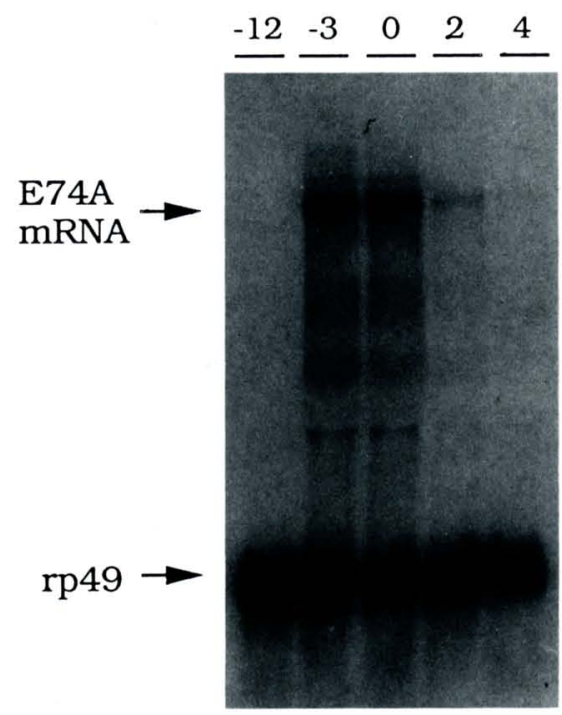

Northern

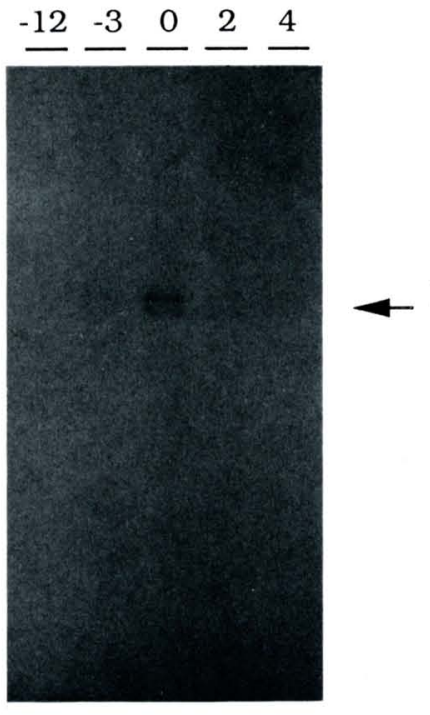

Western
Fig. 4. Temporal pattern of $E 74 A$ mRNA and protein accumulation at the onset of metamorphosis. Groups of $60-100$ staged larvae or prepupae were collected and divided in half for the preparation of RNA and protein samples. Equivalent amounts of total RNA were analyzed by northern blot hybridization using radioactive probes for $E 74 A$ mRNA and rp49 mRNA, as an internal control (O'Connell and Rosbash, 1984). Affinity-purified anti-E74A $\begin{array}{ll}\text { E74A } & \text { antibodies were used to detect } E 74 A \\ \text { protein } & \text { protein on western blots, using alkaline }\end{array}$ phosphatase-conjugated secondary antibodies. (A) E74A mRNA and protein expression at the larval-prepupal transition. E74A protein was detected using a chromogenic alkaline phosphate substrate. (B) E74A mRNA and protein expression in late larvae and prepupae. $E 74 A$ protein was detected using a chemiluminescent alkaline phosphatase substrate. The three bands that do not correspond to $E 74 A$ protein are due to non-specific interactions with the antibodies and are discussed in the text.

B

Hours relative to puparium formation

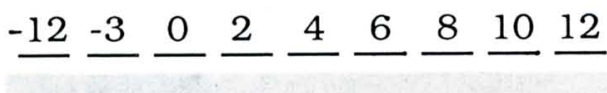

E74A mRNA $\operatorname{rp} 49$

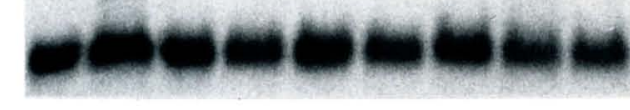

\section{Northern}

membranes. The northern blots were incubated with a ${ }^{32} \mathrm{P}$-labelled single-stranded DNA probe to detect $E 74 \mathrm{~A}$ mRNA, along with a nick-translated rp49 DNA probe (O'Connell and Rosbash, 1984) as an internal control for loading. $E 74 A$ protein was detected by treating the western blots with affinity-purified anti-E74A antibody, followed by alkaline phosphatase-conjugated goat antirabbit secondary antibodies. We have used both the conventional alkaline phosphatase color reaction (Fig. 4A) as well as a chemiluminescent alkaline phosphatase substrate (Fig. 4B) to visualize the immune complex. Chemiluminescence is more sensitive than the alkaline phosphatase color reaction (Fig. 4; see Materials and methods). This experiment was repeated seven times with independently staged populations of animals. Six of those seven experiments gave E74A

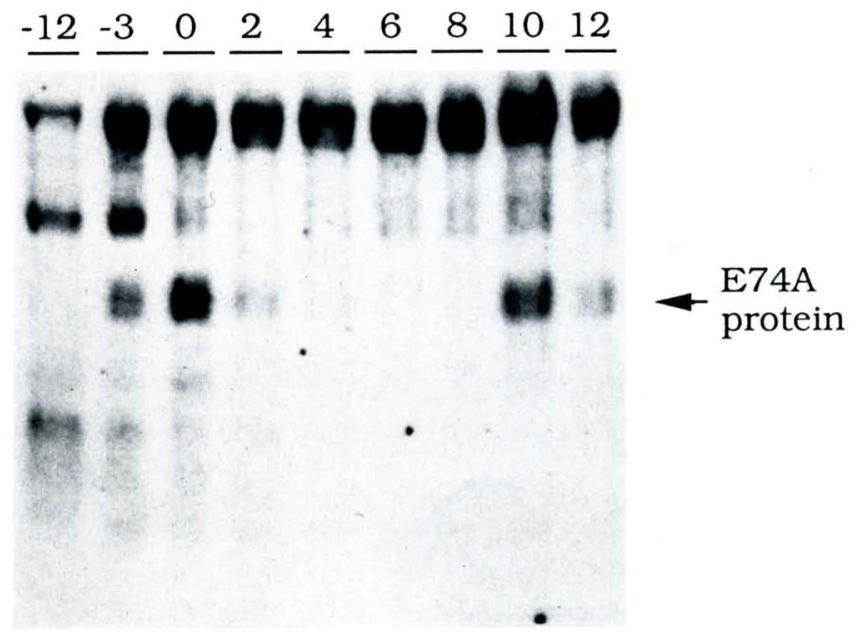

\section{Western}

mRNA and protein patterns similar to those seen in Fig. 4; the one exception showed a higher level of $E 74 \mathrm{~A}$ protein in $-3 \mathrm{~h}$ larvae.

The levels of $E 74 A$ mRNA during late larval and prepupal development are similar to those seen in our previous studies (Thummel et al. 1990). The $6 \mathrm{~kb} E 74 A$ mRNA peaks before puparium formation and in $10 \mathrm{~h}$ prepupae, coincident with the peaks in ecdysone titer (Fig. 4). Two aspects of E74A protein expression distinguish it from the pattern of E74A transcription at the onset of puparium formation. First, $E 74 A$ protein peaks $\sim 2 \mathrm{~h}$ later than $E 74 A$ mRNA at this stage in development. Second, E74A protein is present in a sharp burst of $5-7 \mathrm{~h}$ duration, whereas $E 74 A \mathrm{mRNA}$ is present in a broader $8-10 \mathrm{~h}$ peak (Fig. 4A,B). Interestingly, the pattern is quite different in $10 \mathrm{~h}$ 


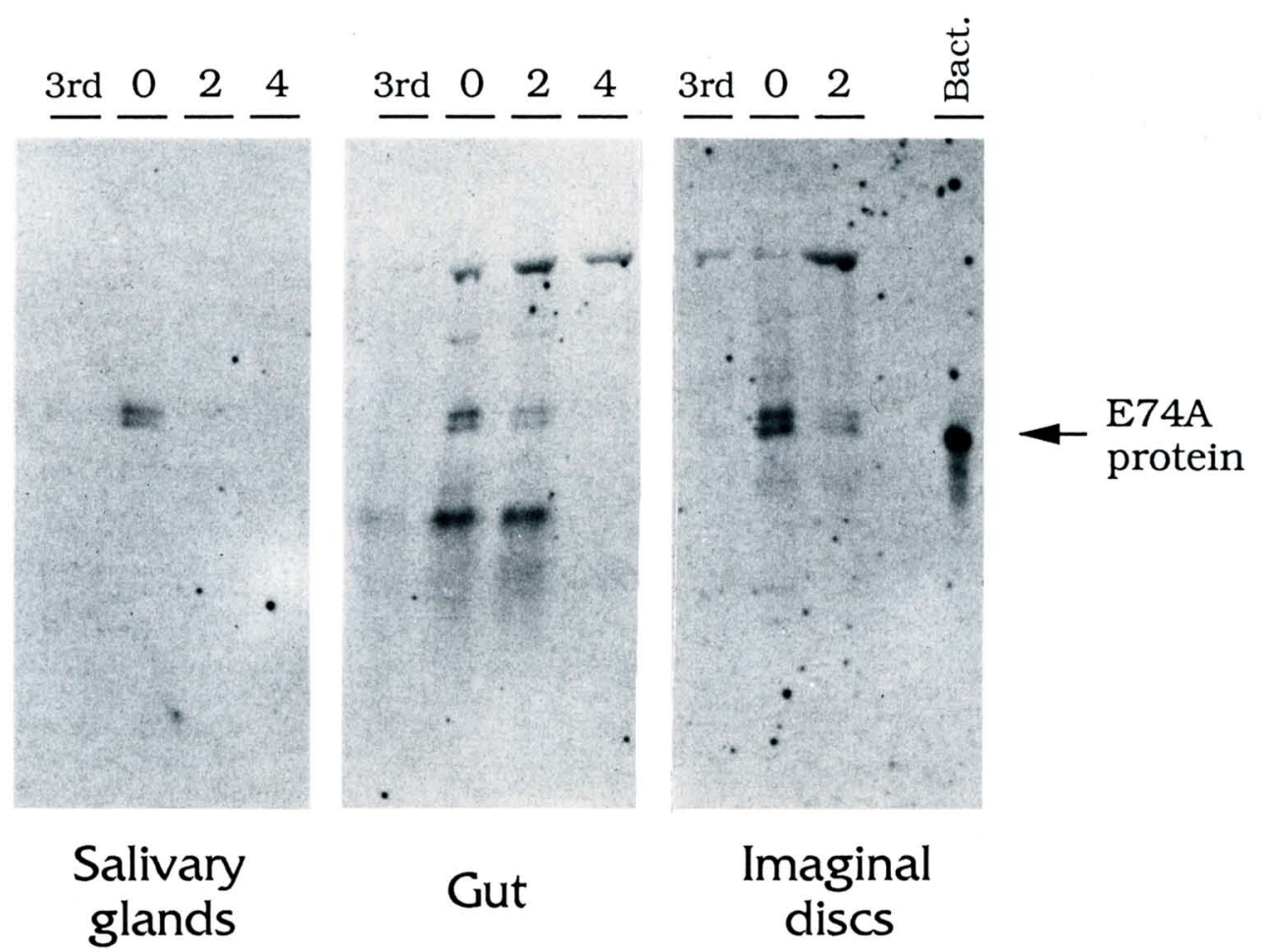

Fig. 5. Temporal pattern of $E 74 \mathrm{~A}$ protein accumulation in isolated salivary glands, gut and imaginal discs. Protein extracts from hand-dissected tissues of staged early wandering larvae (3rd), white prepupae (0), $2 \mathrm{~h}$ prepupae (2), and $4 \mathrm{~h}$ prepupae (4) were analyzed by western blot analysis as described in Fig. 4B. Approximately 15 pairs of salivary glands, or 15 guts (including the proventriculus, gastric caecae, mid-intestine, Malpighian tubules, and hind-intestine), or imaginal discs from 25-40 larvae or prepupae (leg, wing, haltere, and eye-antennal) were used per lane. For each tissue, equivalent amounts of total protein were loaded for each time point, as determined by running a preliminary protein gel and staining with Coomassie blue. The salivary gland samples contain approximately one-half to one-third the amount of total protein present in the gut and disc samples. The background bands in both the gut and disc extracts correspond to those seen in Fig. 4B. The right lane contains $\sim 2.5 \mathrm{ng}$ of $E 74 \mathrm{~A}$ protein in a crude extract prepared from an overproducing strain of bacteria (Urness and Thummel, 1990).

prepupae, when E74A mRNA and protein are synchronously induced and expressed for a brief 2-4 h burst (Fig. 4B). E74A protein can also be detected in extracts from $0-12 \mathrm{~h}$ embryos, in further agreement with previous northern analysis of $E 74 A$ mRNA (Thummel et al. 1990).

$E 74 A$ protein appears as two bands when detected by western blot analysis (Fig. 4). In some preparations, one or two additional bands can be detected, spaced at equal intervals above the predominant bands (data not shown). The lower band comigrates with full-length $110 \times 10^{3} M_{\mathrm{r}} E 74 A$ protein over-expressed in bacteria (Fig. 5; Urness and Thummel, 1990). The upper bands are larger than $E 74 A$ protein by steps of approximately $3-6 \times 10^{3} M_{\mathrm{r}}$, and most likely result from post-translational modifications, such as glycosylation or phosphorylation. Our western blot analysis also detects proteins that are not related to $E 74 A$. In larvae there are two proteins of approximately $140 \times 10^{3} M_{\mathrm{r}}$ in size (Fig. 4B, 5). A $200 \times 10^{3} M_{\mathrm{r}}$ protein can also be detected at all time points, corresponding to one of the most abundant proteins detected in Coomassie stained gels. Since these proteins are also detected in larval and prepupal extracts prepared from an E74 mutant that contains little or no E74A mRNA (Karim and Thummel, 1991), it seems most likely that these bands are caused by non-specific interactions with the anti$E 74 A$ antibody (data not shown). The proteins that contribute to this background pattern are more abundant in certain tissues, such as the gut, and less abundant in others, such as the salivary glands (Fig. 5).

\section{E74A protein is expressed in both larval and imaginal} tissues of white prepupae

$E 74 A$ mRNA is induced by ecdysone in both larval and imaginal tissues of late-third instar larvae (Thummel et al. 1990; Fig. 1). To determine whether E74A protein expression parallels this transcriptional response, we have quantitated $E 74 A$ protein in extracts from individual tissues by western blot analysis. Salivary glands (including the imaginal ring), gut (proventriculus, gastric caecae, mid-intestine, Malpighian tubules and hind-intestine), and imaginal discs (leg, wing, haltere and eye-antennal) were hand-dissected from early wandering larvae and prepupae staged at $2 \mathrm{~h}$ intervals. Protein extracts prepared from these tissues were fractionated by SDS polyacrylamide gel electrophoresis and transferred to nylon membranes. E74A 
$-12 h$ larva
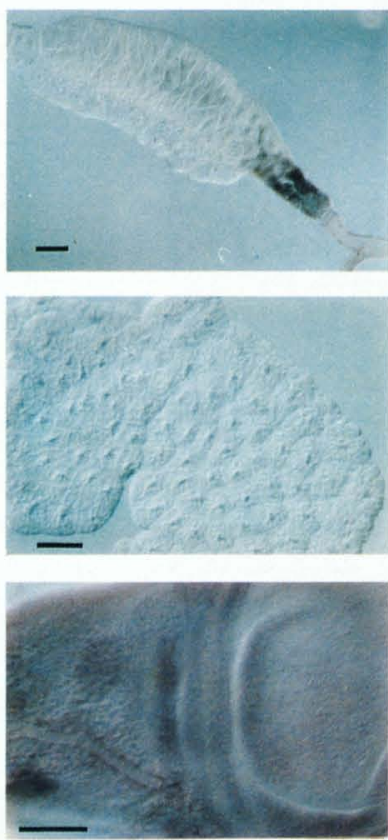

-3h larva
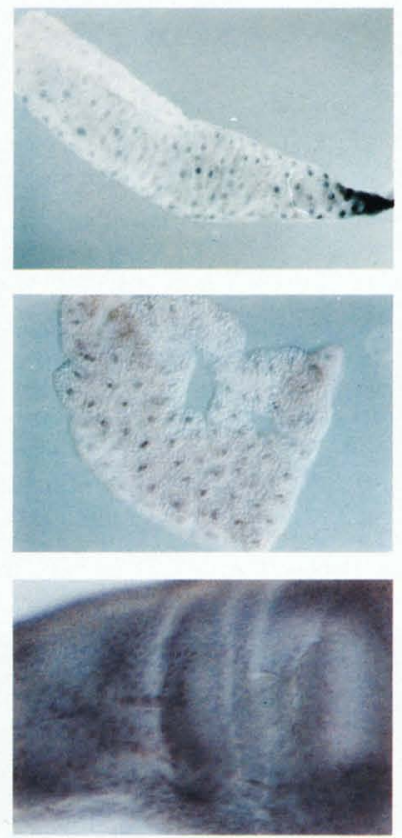

White prepupa
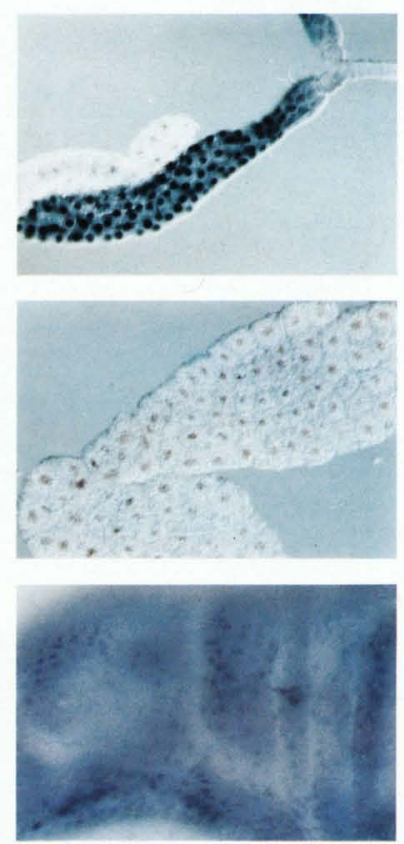

$2 \mathrm{~h}$ prepupa
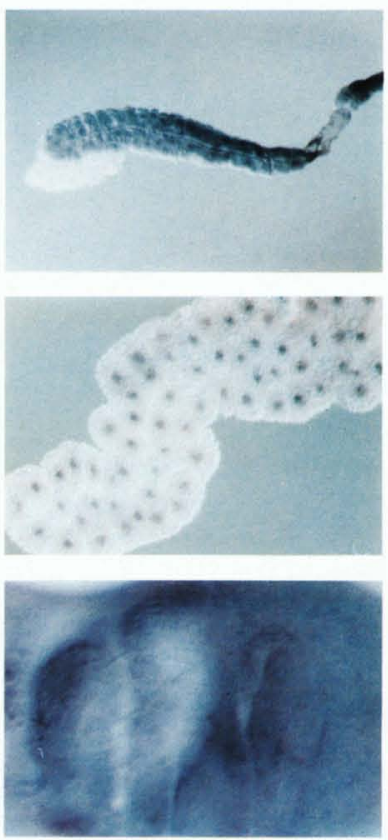

6

Fig. 6. Localization of E74A protein. Salivary glands, fat bodies, and wing imaginal discs were hand-dissected from staged animals and stained with affinity-purified anti- $E 74 A$ antibodies as described in Materials and methods. Bar $=100 \mu \mathrm{m}$.

Fig. 7. Detection of $E 74 A$ protein in glial cells of the brain. (A) A frozen section of a white prepupa stained with the anti-E74A antibodies as described in Materials and methods. Arrows point to the large nuclei of the glial cells surrounding the neuropil. Nuclear protein can also be detected in the salivary glands (S), imaginal discs (D), and proventriculus (P). This section of the brain does not contain cells from the proliferation centers.

Antibody stains of both intact brains and sectioned late larvae and prepupae failed to detect $E 74 A$ protein in the proliferation centers of the brain (data not shown). (B) In situ hybridization to localize $E 74 A$ RNA in a frozen section of a late-third instar larva. Within the brain, the highest levels of E74A RNA are restricted to the proliferation centers (white arrow) and the glial cells (black arrows). Anterior is to the left. 
protein was detected as described above with the chemiluminescent alkaline phosphatase substrate.

$E 74 A$ protein can be detected in all three tissues as two bands with highest levels in white prepupae (Fig. 5). In agreement with our analyses of E74A RNA by northern blot hybridizations (Karim and Thummel, 1991) and in situ hybridizations (Fig. 1), salivary glands express the highest levels of E74A protein (there is onehalf to one-third the amount of total protein in the salivary gland samples relative to samples from the other tissues). E74A protein is low in early wandering larvae (Fig. 5) and stationary late-third instar larvae (data not shown). The protein level peaks in white prepupae and declines significantly within the next $2 \mathrm{~h}$, paralleling the rapid decrease in $E 74 A$ RNA in the salivary gland (Fig. 1). That peak levels of E74A protein are in the salivary glands of white prepupae, when the E74A RNA level is relatively low and the $74 \mathrm{EF}$ puff has regressed, suggests that the delay in $E 74 A$ protein accumulation seen in intact animals (Fig. 4) is a reflection, at least in part, of salivary gland expression.

Both gut and imaginal discs also contain peak levels of $E 74 A$ protein in white prepupae. Unlike salivary glands, however, $E 74 A$ protein is still clearly detectable in these tissues by $2 \mathrm{~h}$ after puparium formation. This persistence in protein expression follows the pattern of transcription, in that E74A RNA is still present in the gut and imaginal discs of $1.5 \mathrm{~h}$ prepupae (Fig. 1E,F). Gut contains the highest levels of background proteins, consistent with antibody staining of whole-mount tissues where the gut displays non-nuclear, non-specific staining in all stages examined (data not shown).

\section{E74A protein is located in the nucleus}

Antibody staining of whole-mount organs dissected from late wandering larvae and early prepupae allowed us to determine the cellular and subcellular distribution of $E 74 A$ protein at the onset of metamorphosis. Tissues were hand-dissected, fixed with formaldehyde, and incubated with affinity-purified anti-E74A antibodies. Bound antibodies were detected with horseradish peroxidase-conjugated goat anti-rabbit antibodies and diaminobenzidine as a chromogenic substrate. A monoclonal antibody directed against a ubiquitous nuclear antigen was used as a positive control to ensure that the tissues had been properly permeabilized and secondary antibody alone was used as a negative control (data not shown).

Anti-E74A antibody stains of three representative tissues are shown in Fig. 6. E74A protein is localized in the nuclei of both larval and imaginal tissues. This is consistent with the DNA-binding properties of $E 74 \mathrm{~A}$ protein as well as antibody stains that detect $E 74 \mathrm{~A}$ protein bound to the salivary gland polytene chromosomes (Urness and Thummel, 1990). E74A protein in the imaginal discs could be most clearly detected in the nuclei of cells in the peripodial membranes (Fig. 6). Although E74A protein may be present in other imaginal disc nuclei, it is at significantly lower levels, reflecting the relative levels of $E 74 A$ RNA as determined by in situ hybridization (Fig. 1).

The levels of nuclear $E 74 A$ protein begin to increase at the end of larval development, coincident with the increasing ecdysone titer and the activation of $E 74 \mathrm{~A}$ transcription. E74A protein is most abundant at the white prepupal stage (Fig. 6). Although some staining can be seen in the cytoplasm of $2 \mathrm{~h}$ prepupal salivary glands, this does not appear to be due to $E 74 A$ protein since it is also seen in control experiments when no primary antibody is used (data not shown). The temporal pattern of nuclear $E 74 A$ protein expression in salivary glands is consistent with that seen by western blot analysis (Fig. 5). In contrast to the salivary gland expression pattern, E74A protein is still present in both fat bodies and imaginal discs isolated from $2 \mathrm{~h}$ prepupae (Fig. 6). This agrees with our western blot analysis of protein extracts prepared from imaginal discs (Fig. 5) as well as the persistence of $E 74 A$ RNA in imaginal discs of $1.5 \mathrm{~h}$ prepupae (D, Fig. $1 \mathrm{E}, \mathrm{F})$. Unfortunately, the levels of $E 74 A$ RNA in fat bodies are difficult to determine by in situ hybridization. However, studies of the effects of ecdysone on the puffing pattern of fat body polytene chromosomes showed that the 74EF puff regresses more slowly in this tissue than it does in salivary glands (Richards, 1982). This delay in puff regression could be due to prolonged E74A transcription in fat bodies.

Nuclear protein was also detected in other white prepupal tissues treated with anti-E74A antibodies including gastric caecae, trachea, ring gland, garland cells, Malpighian tubules, brain, imaginal ring of the salivary gland, imaginal cells of the gut, lymph glands, and genital, eye-antennal and leg discs (data not shown). However, when examined, the level of induction was not as dramatic as that seen in salivary glands, fat bodies and imaginal discs. Furthermore, without a defined null E74A mutation for use as a negative control, we could not be certain that the nuclear stain in these tissues accurately reflected the levels of $E 74 A$ protein.

\section{E74A RNA in the proliferation centers of the brain does not appear to be translated}

In situ detection of E74A RNA in tissue sections indicated high levels of expression in two cell types within the larval brain: the glial cells surrounding the neuropil and the proliferation center (Fig. 1 and 7B). Our initial effort to detect $E 74 \mathrm{~A}$ protein in intact larval brains by antibody staining was complicated by the low permeability of this tissue. In particular, we were concerned that it might be difficult to detect E74A expression in these cell types since they are both buried in the central-most portion of the supraesophageal ganglia. To minimize our problems with permeability, frozen sections were prepared from white prepupae and stained with the affinity-purified anti-E74A antibody as described above. In agreement with our whole-mount antibody stains, nuclear protein can be detected in most prepupal tissues, including the salivary gland, proventriculus and imaginal discs (Fig. 7A). In the nervous 
system, staining is most abundant in the glial cells that border the cortex and the neuropil (arrows, Fig. 7A), in agreement with the relatively high levels of $E 74 A$ RNA present in these cells (black arrows, Fig. 7B). Similarly, very little or no $E 74 A$ RNA or protein is present in the other cells of the brain cortex. However, upon examining serial sections of white prepupae, no E74A protein could be detected in the proliferation centers of the brain, which express high levels of E74A RNA (Fig. 1; data not shown). This discrepancy between E74A RNA and protein expression may reflect some form of post-transcriptional regulation.

\section{Discussion}

E74A is widely expressed in many larval and imaginal tissues

The tissue coordination model predicts that each ecdysone pulse activates unique combinations of early regulatory genes in a precise spatially and temporally defined manner. Although some early genes may be expressed in a cell- or tissue-specific manner, others may be more widely expressed to perform pleiotropic functions in the regulatory response. $E 74 A$ clearly belongs to this latter class. Late-third instar tissues expressing E74A RNA include the salivary gland, brain, imaginal discs (leg, wing, haltere, eye-antennal, genital), muscle, fat body, gastric caecae, proventriculus, mid-intestine, ring gland, trachea, Malpighian tubules and epidermis (Fig. 1,2). Tissues not shown in which we have detected $E 74 A$ RNA include garland cells, hind-intestine, lymph glands, and the imaginal ring and duct cells of the salivary gland. Thus, not only is $E 74 A$ expressed in both larval and imaginal tissues, which undergo completely opposite developmental responses to ecdysone, but it is also present in many tissues within each of these classes.

$E 74 A$ transcription is relatively uniform throughout the larval tissues, including the fat bodies, salivary glands and gut. This contrasts with the distinctive spatial pattern of E74A transcription in different cell types of the imaginal discs and brain. From its initial induction in late-third instar larvae, E74A RNA is more abundant in what appears to be the peripodial membrane of the imaginal discs, the glial cells surrounding the neuropil, and the proliferation centers of the brain (Fig. 1A,B). RNA levels in the glial cells decrease at approximately the same rate as that seen in most tissues, such that the levels are very low in $1.5 \mathrm{~h}$ prepupae. Relatively high levels of $E 74 A$ RNA persist, however, in the peripodial membranes and proliferation centers of $1.5 \mathrm{~h}$ prepupae. The larval cells of the gut also continue to have high levels of $E 74 A$ RNA at this stage, relative to the RNA levels in the salivary glands (Fig. 1E,F). These temporal patterns of transcription are reflected by prolonged expression of $E 74 \mathrm{~A}$ protein in the gut and imaginal discs, relative to salivary gland expression (Fig. 5). E74A protein can also be clearly resolved in the nuclei of cells in the peripodial membranes of the imaginal discs of white and $2 \mathrm{~h}$ prepupae (Fig. 6).

The functional significance of these differences in the relative levels and timing of $E 74 A$ expression is not clear, since these cell types do not share any apparent functional similarities. Most larval cells, including those of the gut, undergo histolysis during metamorphosis (Bodenstein, 1965; Robertson, 1936). The peripodial membrane aids in the evagination of the imaginal discs and differentiates into specific adult cuticular structures (Milner et al. 1984). The proliferation centers contain cells that are actively undergoing mitosis throughout the larval and early pupal stages of development. These cells form the optic lobes of the adult brain during metamorphosis (White and Kankel, 1978). It is possible that information regarding the functional consequences of $E 74 A$ expression in these cell types could be derived from histological analysis of E74 mutants, all of which die during pupal development (Burtis, 1985).

Our in situ hybridization studies also indicate that $E 74 A$ transcription may be repressed at different times in different larval tissues. This result is similar to that of Richards (1982), who found that the 74EF puff regresses more slowly in fat bodies than it does in salivary glands. As discussed more extensively below, the giant polytene nuclei of the larval tissues afford an opportunity to observe nascent $E 74 A$ transcripts within the $74 \mathrm{EF}$ puff. Nascent transcripts can be clearly resolved in the nuclei of late wandering larval salivary glands, proventriculus, mid-intestine, gastric caecae, and trachea and are no longer detectable in white prepupae (Fig. 2). This is consistent with repression of $E 74 A$ transcription just prior to puparium formation, leading to complete regression of the salivary gland $74 \mathrm{EF}$ puff (Ashburner, 1967), and reduced levels of E74A mRNA in white prepupae (Fig. 4). Subnuclear $E 74 A$ RNA can also be clearly detected in the fat bodies of late wandering larvae. We did not detect expression in white prepupal fat bodies, although low levels of $E 74 A$ RNA could be obscured by the opacity of the tissue (data not shown). The Malpighian tubules, mouth part muscle and ring gland show a different temporal response in that nuclear E74A RNA is present at lower but detectable levels in these tissues at the white prepupal stage (Fig. 2B). E74A RNA in the nuclei of Malpighian tubules can be detected as late as $2 \mathrm{~h}$ after pupariation (data not shown). The Malpighian tubules are unique among larval organs in that they do not undergo histolysis during metamorphosis, but rather survive intact and continue to function in the adult fly (Bodenstein, 1965). In addition, some of the larval muscles, including those that support the mouth parts, histolyze later than other larval tissues (Bodenstein, 1965) and the ring gland is thought to histolyze late during metamorphosis since the ecdysone titer continues to rise during the first two days of pupal development (Handler, 1982). The delayed repression of E74A transcription in these three tissues could be a consequence of their survival through the early stages of metamorphosis. It is also possible that E74A may play an active role in controlling this delay in histolysis. 
In summary, our characterization of the spatial distribution of $E 74 A$ transcription at the onset of metamorphosis indicates that E74A is expressed in most, if not all, ecdysone target tissues. If, indeed, $E 74 A$ is an activator of late gene expression as we have proposed earlier (Urness and Thummel, 1990), then it must do so in a global manner, perhaps by coordinating the activation of different tissue-specific sets of late genes. Initial analysis of the expression pattern of E75, an early ecdysone-inducible gene isolated from the $75 \mathrm{~B}$ puff locus, indicates that it too is broadly expressed in both larval and imaginal tissues (Feigl et al. 1989; Segraves, 1988). Like E74, this gene is long and complex and encodes multiple DNA-binding proteins that appear to function in a regulatory manner. It is possible that different relative levels of early gene products could provide the combinatorial information needed to activate tissue-specific sets of late genes. Alternatively, other early ecdysone-inducible regulatory genes may display more restricted spatial patterns of expression in order to account for the diversity of developmental pathways that are activated during metamorphosis.

Nascent E74A transcripts can be detected in the $74 E F$ puff by in situ hybridization

The highest levels of $E 74 A$ RNA in late-third instar larval tissues are localized in the nucleus (Fig. 1A,B). This was originally observed by Bonner and Pardue (1977), long before the cloning of E74, by measuring the relative levels of cytoplasmic and nuclear RNA derived from the 74EF puff using in situ hybridization to polytene chromosomes. In situ detection of E74A RNA in whole-mount late wandering larval organs by the digoxygenin-alkaline phosphatase system revealed a discrete subnuclear localization (Figs 2, 3). It seems likely that the highly polytenized DNA in the larval tissues (particularly the salivary gland) and the $60 \mathrm{~kb}$ length of the $E 74 A$ transcription unit provide a locally high concentration of nascent $E 74 A$ transcripts following ecdysone activation of its promoter. We conclude that the subnuclear signal detected by in situ hybridization represents elongating E74A RNA at its site of synthesis in the 74EF puff based on two observations. First, the signal is restricted to a discrete region within the nucleus. Dual-channel detection of both the polytene chromosomes and E74A RNA localized the RNA signal within one of two adjacent decondensed regions in the polytene chromosomes, which strongly resemble the $74 \mathrm{EF}$ and $75 \mathrm{~B}$ early ecdysone-induced puffs (Fig. 3B,C). Second, an identical subnuclear signal was generated using probes derived from either the first $E 74 A$ exon or the first intron of the primary transcript. The signal from the intron-specific probe was reproducibly weaker than that generated by the exonspecific probe (data not shown). This is consistent with our kinetic studies of $E 74 A$ splicing which demonstrated excision of the first $E 74 A$ intron from nascent transcripts, between 30 and $45 \mathrm{~min}$ after transcriptional initiation (LeMaire and Thummel, 1990). Although in situ hybridization allowed us to readily identify the subnuclear $E 74 A$ RNA signal, it was not of sufficient sensitivity to detect the more diffuse cytoplasmic E74A RNA.

Nascent transcripts are clearly detectable in salivary gland nuclei at approximately $3 \mathrm{~h}$ before puparium formation (Fig. 2A), when the $74 \mathrm{EF}$ puff is expanded (Ashburner, 1967). The subnuclear signal is no longer detectable in white prepupae (Fig. 2A), when the 74EF puff has regressed (Ashburner, 1967). This correlation between nascent $E 74 A$ transcripts in the larval salivary gland and puff formation at 74EF provides support for the longstanding hypothesis that puffing is due to an accumulation of nascent transcripts on the DNA resulting from high levels of transcription (Beerman, 1972; Berendes, 1968; Pelling, 1972).

The nascent E74A transcripts are highly localized within the chromosome with distinct borders on all sides. We have found no evidence for diffusion of RNA from its site of synthesis, unidirectional transport of the RNA, or specific tracks of RNA transport as have been described by Lawrence et al. (1989). It is possible that this is due to some artifact of our technique, for example, conditions in which transcription elongation ceases but diffusion proceeds. It is interesting to note that in 45 of 50 nuclei examined the site of E74A RNA synthesis adjoins the nuclear membrane. Although this could provide a means to deliver mRNA directly into the cytoplasm, no convincing evidence was found for this form of unidirectional transport. Our localization of the 74EF puff differs somewhat from that determined by Hochstrasser et al. (1986) in intact salivary gland nuclei. In studying the three dimensional spatial organization of the salivary gland chromosome arms, they found $74 \mathrm{EF}$ to be within $1 \mu \mathrm{m}$ of the nuclear membrane in only 15 of 24 nuclei. Although this discrepancy could be due to strain variation, it is probably not caused by differences in staging since they also demonstrated that the overall conformation of the chromosome arms does not change significantly upon treatment with ecdysone (Hochstrasser and Sedat, 1987).

\section{The E74A protein is restricted to the nucleus and is post-translationally modified}

The $6 \mathrm{~kb}$ E74A mRNA contains a 5' leader that is 1891 nucleotides in length with 17 AUG triplets. Extensive characterization of $E 74 A$ transcript structure by cDNA cloning, sequencing, northern blots and S1 analyses, has revealed no evidence for truncated mRNAs that might lack this leader sequence (Burtis, 1985; Burtis et al. 1990). According to the scanning hypothesis for translational initiation, the length and complexity of this leader should greatly diminish or prevent translation of the long open reading frame that lies downstream (Kozak, 1989). Nevertheless, affinitypurified anti-E74A antibodies detect a $110 \times 10^{3} M_{\mathrm{r}}$ protein in western blots of extracts prepared from white prepupae. This protein co-migrates during SDSpolyacrylamide gel electrophoresis with full-length $E 74 A$ protein synthesized in bacteria (Fig. 5). Our ability to detect readily $E 74 A$ protein in prepupal 
extracts by western blot analysis and the intense nuclear stain seen in salivary glands suggest that its level of expression is not unusually low. In one experiment, by comparing the signal generated from a prepupal protein extract with known amounts of $E 74 A$ protein from bacteria, we estimated that one white prepupa contains $0.2 \mathrm{ng}$ of $E 74 \mathrm{~A}$ protein (assuming total recovery of protein in the extraction procedure). Further evidence obtained from $\mathrm{P}$ element transformation studies suggests that the $5^{\prime}$ leader does not seriously inhibit E74A protein synthesis (C.S.T., unpublished results). Some mechanism may exist to overcome the potential inhibitory effects of the $E 74 A 5^{\prime}$ leader. One possibility is that the $E 74 A$ leader contains an internal ribosome binding site, similar to that used by poliovirus for $5^{\prime}$ cap-independent translation (Pelletier and Sonenberg, 1988). This would allow ribosomes to circumvent the multiple short open reading frames in the $5^{\prime}$ leader and load directly upstream from the protein coding region. Preliminary results indicate that the long 5 ' leader on the Drosophila Antennapedia P1 mRNA contains an internal ribosome binding site that could facilitate translation of its long open reading frame (M. P. Scott and P. Sarnow, personal communication). Experiments are currently underway to detect sequences in the $E 74 \mathrm{~A}$ $5^{\prime}$ leader that might function in this manner. Such sequences would provide a logical target for mediating post-transcriptional regulation of $E 74 A$ expression.

$E 74 A$ protein detected by antibody staining of intact salivary glands and imaginal discs is induced and repressed with kinetics that parallel those determined by western blot analysis, peaking in white prepupae (Figs 5,6 ). The strictly nuclear location of the E74A protein is consistent with our biochemical experiments demonstrating that it functions as a site-specific DNAbinding protein (Urness and Thummel, 1990).

Western blot analysis revealed additional bands migrating more slowly than the $110 \times 10^{3} M_{\mathrm{r}} E 74 A$ protein. These forms most likely represent posttranslational modifications of $E 74 A$ protein, due perhaps to phosphorylation or glycosylation. Similar modifications have been shown to alter the regulatory properties of some transcription factors (Jackson and Tijan, 1988; Mylin et al. 1990). Western blot analysis of extracts prepared from salivary glands, guts and imaginal discs showed the same relative ratios of unmodified to modified forms of the protein (Fig. 5). Interestingly, however, western blots of extracts prepared from Drosophila embryos or Schneider tissue culture cells engineered to overproduce $E 74 \mathrm{~A}$ protein show only the unmodified $110 \times 10^{3} M_{\mathrm{r}}$ form (data not shown). It is thus possible that post-translational modification of $E 74 A$ protein may be regulated in a stage- or tissue-specific manner.

The half-life of $E 74 A$ protein in prepupae is very short, on the order of $45 \mathrm{~min}$, based on its more than 5 -fold decrease during the first $2 \mathrm{~h}$ of prepupal development (Fig. 4). The E74A amino acid sequence contains one good match to the PEST consensus sequence (amino acids 409-444, Burtis et al. 1990) which has been implicated in protein degradation
(Rechsteiner, 1988). Mutations in the PEST sequence of a Drosophila embryonic regulatory protein, fushi tarazu, have been shown to increase the stability of this protein and cause dramatic developmental abnormalities (Kellerman et al. 1990).

\section{E74A expression appears to be post-transcriptionally regulated}

In most cases, the spatial and temporal distributions of $E 74 A$ RNA and protein were very similar. We noted two exceptions to this correspondence. First, we did not detect $E 74 A$ protein in the proliferation centers of the brain where E74A RNA accumulates to very high levels and persists into early prepupae (Fig. 1). It is not clear what biological significance this may have, although it remains possible that the mRNA itself serves an important function in these cells. Characterization of Drosophila embryonic regulatory genes has revealed several examples of spatially restricted protein expression (Cabrera, 1990; Gaul et al. 1987; Macdonald and Struhl, 1986; Mlodzik and Gehring, 1987; Riggleman et al. 1990).

We also noted one significant temporal difference between $E 74 A$ mRNA and protein levels: the peak of $E 74 A$ protein accumulation lags behind the peak of $E 74 A$ mRNA by $\sim 2 \mathrm{~h}$ at the larval-prepupal transition. This delay was seen reproducibly by northern and western blot analyses of extracts prepared from staged animals (Fig. 4). In addition, the high level of $E 74 \mathrm{~A}$ RNA in late-third instar larvae as detected by in situ hybridization (Fig. 1A,B) was not reflected in the antibody stains of tissues from that stage; rather, the highest levels of nuclear $E 74 A$ protein were present in white prepupae (Fig. 6). Although this delay could be simply explained by a slow accumulation of the $E 74 \mathrm{~A}$ protein product due to some inherent property of $E 74 \mathrm{~A}$ protein synthesis, it does not occur in response to the ecdysone pulse $10 \mathrm{~h}$ later. At that time, E74A mRNA and protein are simultaneously expressed for the same 2-4 $\mathrm{h}$ period. That the delay occurs at one stage and not another argues that it is due to an active form of posttranscriptional regulation, rather than a passive mechanism built into the translation of E74A mRNA. Alternatively, the delay may be caused by a general property of protein expression in late-third instar larvae that does not exist in $10 \mathrm{~h}$ prepupae.

The regulatory mechanisms that might account for the absence of E74A translation in the proliferation centers or the temporal delay in white prepupae remain unclear. However, the unusual length and complexity of the E74A 5' leader leads us to suspect that this sequence may impose some form of translational regulation on E74A expression. Translation of both the murine protamine 1 (Braun et al. 1989) and Drosophila mst(3) gl-9 (Kuhn et al. 1988) mRNAs is delayed by several days during spermatogenesis, due to short sequences in the untranslated regions of those transcripts. One possible mechanism for translational regulation of $E 74 A$, as has been documented for ferritin expression (Rouault et al. 1988), is that translation might be controlled by a trans-acting factor that 


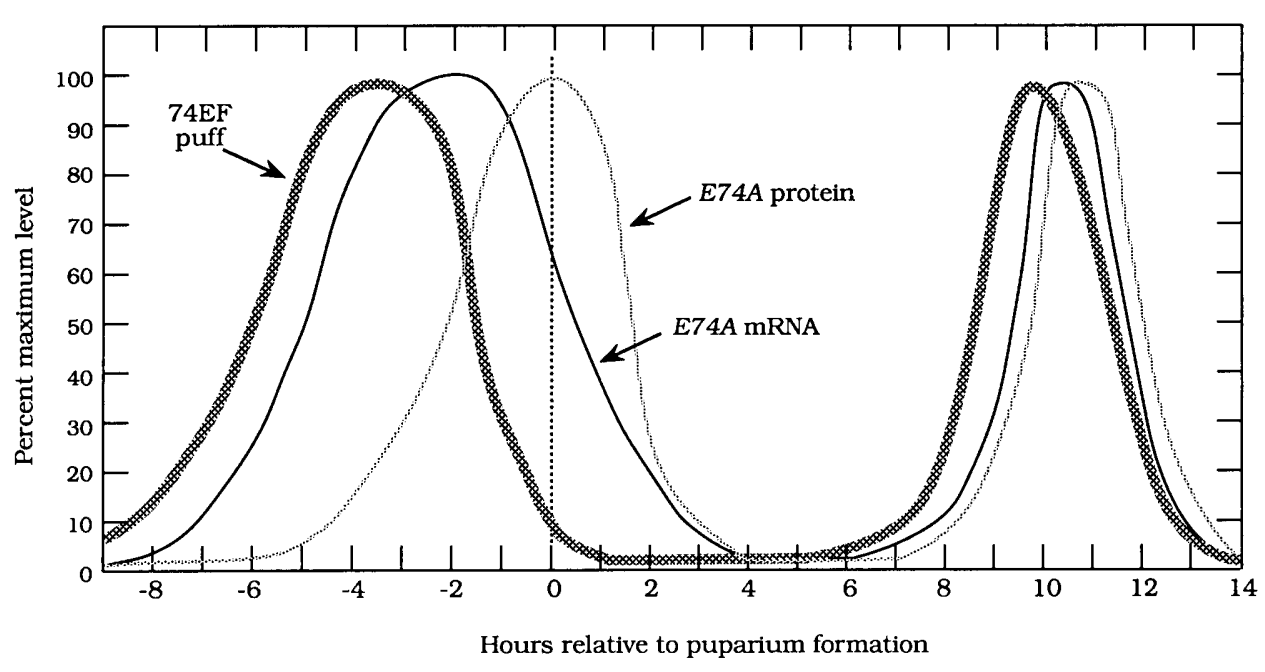

Fig. 8. Schematic

representation of the temporal patterns of $E 74 A$ expression at the onset of metamorphosis. The time course of the 74EF puff is adapted from Becker (1959) and Ashburner (1967). The levels of E74A mRNA and protein are approximated from the data in Thummel et al. (1990), Karim and Thummel (1991), and Fig. 4. The ordinate shows the approximate percent of the maximum size (74EF puff) or level (mRNA or protein accumulation) achieved. The abscissa is a measurement of hours, relative to puparium formation $(0=$ white prepupae $)$. interacts with sequences in the $5^{\prime}$ leader of the $E 74 \mathrm{~A}$ mRNA.

\section{The timing of E74A expression at the onset of metamorphosis}

This study completes our characterization of the temporal pattern of $E 74 A$ expression at the onset of metamorphosis. E74A expression has been monitored in terms of puffing at 74EF (Ashburner, 1967; Ashburner et al. 1974), transcriptional elongation rate (Thummel et al. 1990), subnuclear RNA in polytene tissues, mature $6 \mathrm{~kb}$ mRNA (Thummel et al. 1990; Karim and Thummel, 1991), and $110 \times 10^{3} M_{\mathrm{r}}$ protein product. A summary of the temporal profiles of $E 74 \mathrm{~A}$ expression in salivary glands is depicted in Fig. 8. The timing in late larvae is, of necessity, only an approximation due to the difficulty in staging these organisms. The times are consistent with both in vitro and in vivo studies. As discussed above, both puffing and subnuclear $E 74 A$ RNA in the salivary gland appear to be synchronous, consistent with the notion that puffing is due to an accumulation of nascent transcripts on the DNA. The earliest manifestation of E74A expression is an increase in puff size as the $E 74 A$ promoter is activated by ecdysone and RNA polymerases begin to load onto the E74A transcription unit. Maximum polymerase density is achieved after $1 \mathrm{~h}$, when spliced $E 74 A$ mRNA begins to appear in the cytoplasm (see Discussion, Thummel et al. 1990). E74A repression is first evident as a decrease in the size of the $74 \mathrm{EF}$ puff at $\sim 4 \mathrm{~h}$ after its initial induction. This is presumably due to an inhibition of $E 74 A$ transcriptional initiation and a reduction in the number of nascent transcripts as RNA polymerases unload off the $3^{\prime}$ end of the unit. E74 A mRNA continues to accumulate for an additional $1-2 \mathrm{~h}$, after which the supply of primary transcripts has been exhausted and mRNA levels begin to decline. Both nascent E74A RNA, as visualized by in situ hybridization, and the 74EF puff are no longer visible at puparium formation.

$E 74 A$ protein shows a significant lag in its accumu- lation. The protein product is present for a relatively short duration of $\sim 5-7 \mathrm{~h}$ and peaks in white prepupae, $\sim 2 \mathrm{~h}$ after the peak of E74A mRNA. Thus, E74A appears to be designed to delay the appearance of its encoded protein product at the onset of metamorphosis. The $1 \mathrm{~h}$ delay in the initial appearance of mature $E 74 A$ mRNA combined with the several hour delay in the appearance of $E 74 A$ protein leads to a cumulative 8-10 h period between $E 74 A$ promoter activation and the peak of $E 74 A$ protein accumulation (Fig. 8). Since $E 74 A$ protein is predicted to be a transcriptional regulator and binds to a subset of the late ecdysoneinduced puffs (Urness and Thummel, 1990), it is possible that this temporal delay in protein accumulation may contribute to the correct timing of late gene activation.

This ordered progression of $74 \mathrm{EF}$ puff formation and E74A mRNA and protein accumulation spread out over a $10-12 \mathrm{~h}$ period is greatly condensed in response to the prepupal pulse of ecdysone (Figs $4 \mathrm{~B}, 8$ ). The increasing ecdysone titer in $8 \mathrm{~h}$ prepupae triggers $74 \mathrm{EF}$ puff induction followed $\sim 1 \mathrm{~h}$ later by an essentially simultaneous increase in E74A mRNA and protein. Both mRNA and protein are expressed for a brief duration of $4 \mathrm{~h}$. The rapid turnover of both $E 74 \mathrm{~A}$ mRNA and protein is most likely due to an active targeted degradation pathway. Temporal studies of the $71 \mathrm{E}$ late ecdysone-induced gene cluster revealed that they are selectively deadenylated and then rapidly turned over following puparium formation (Restifo and Guild, 1986). A similar mechanism may be used to clear the system of the early transcripts that encode the regulatory components in the ecdysone hierarchy.

We thank Sean Carroll for helpful suggestions on affinitypurification of antibodies and staining of larval organs, Henry Krause for suggesting acetonitrile as a means of inhibiting proteolysis, Bob Weiss for help with chemiluminescence, Seymour Benzer for the generous gift of $8 \mathrm{C} 5$ mouse monoclonal antibodies, and David Gard and Ed King for help with the confocal microscope. We thank Shige Sakonju for helpful discussions and Shige Sakonju, Bob Riggleman, and Andy Andres for critical comments on the manuscript. This 
research was supported by the Cancer Training Grant 5 T32 CA09602 (to L.B.) and the Howard Hughes Medical Institute.

\section{References}

Ashburner, M. (1967). Patterns of puffing activity in the salivary gland chromosomes of Drosophila. I. Autosomal puffing patterns in a laboratory stock of Drosophila melanogaster. Chromosoma 21, 398-428.

Ashburner, M., Chihara, C., Meltzer, P. and Richards, G. (1974). Temporal control of puffing activity in polytene chromosomes. Cold Spring Harbor Symp. quant. Biol. 38, $655-662$.

BeCKER, H. J. (1959). Die puffs der speicheldrüsenchromosomen von Drosophila melanogaster. I. Beobachtungen zur verhalten des puffmusters in normalstamm und bei zwei mutanten, giant und lethal-giant-larvae. Chromosoma 10, 654-678.

BeERman, W. (1972). Chromomeres and genes. In Developmental Studies on Giant Chromosomes 4 (ed. W. Beerman) pp. 1-33. New York: Springer-Verlag.

Berendes, H. D. (1968). Factors involved in the expression of gene activity in polytene chromosomes. Chromosoma 24, 418-437.

Bodenstein, D. (1965). The postembryonic development of Drosophila. In Biology of Drosophila (ed. M. Demerec) pp. 275-367. New York: Hafner Publishing Company.

Bonner, J. J. and Pardue, M. L. (1977). Polytene chromosome puffing and in situ hybridization measure different aspects of RNA metabolism. Cell 12, 227-234.

Braun, R. E., Peschon, J. J., Behringer, R. R., Brinster, R. L. ANd Palmiter, R. D. (1989). Protamine $3^{\prime}$-untranslated sequences regulate temporal translational control and subcellular localization of growth hormone in spermatids of transgenic mice. Genes Dev. 3, 793-802.

BurTIS, K. C. (1985). Isolation and characterization of an ecdysone-inducible gene from Drosophila melanogaster. Ph.D. thesis, Stanford University, Stanford, California.

Burtis, K. C., Thummel, C. S., Jones, W. C., Karim, F. D. and Hogness, D. S. (1990). The Drosophila 74EF early puff contains $E 74$, a complex ecdysone-inducible gene that encodes two ets-related proteins. Cell 61, 85-99.

Cabrera, C. V. (1990). Lateral inhibition and cell fate during neurogenesis in Drosophila: the interactions between scute, Notch and Delta. Development 109, 733-742.

Carroll, S. B. And Whyte, J. S. (1989). The role of the hairy gene during Drosophila morphogenesis: stripes in imaginal discs. Genes Dev. 3, 905-916.

Clever, U. and Karlson, P. (1960). Induktion von puffveränderungen in den speicheldrüsenchromosomen von Chironomus tentans durch ecdyson. Expl Cell. Res. 20, 623-626.

Feigl, G., Gram, M. and Pongs, O. (1989). A member of the steroid hormone receptor gene family is expressed in the 20 $\mathrm{OH}$-ecdysone inducible puff $75 \mathrm{~B}$ in Drosophila melanogaster. Nucl. Acids Res. 17, 7167-7178.

Gaul, U., Seifert, E., Schuh, R. and Jäckle, H. (1987). Analysis of Krüppel protein distribution during early Drosophila development reveals posttranscriptional regulation. Cell $\mathbf{5 0}$, $639-647$.

Guo, L. H., Stepién, P. P., Tso, J. Y., Brousseau, R., Narang, S., Thomas, D. Y. AND Wu, R. (1984). Synthesis of human insulin gene VIII. Construction of expression vectors for fused proinsulin production in Escherichia coli. Gene 29, 251-254.

HaFen, E. ANd Levine, M. (1986). The localization of RNAs in Drosophila tissue sections by in situ hybridization. In Drosophila a practical approach (ed. D. B. Roberts) pp. 139-157.

Washington DC: IRL Press.

HANDlER, A. M. (1982). Ecdysteroid titres during pupal and adult development in Drosophila melanogaster. Devl Biol. 93, 73-82.

Harlow, E. And Lane, D. (1988). Antibodies - A Laboratory Manual. Cold Spring Harbor Lab, New York: Cold Spring Harbor Press.

Hochstrasser, M., Mathog, D., Gruenbaum, Y., Saumweber,
H. ANd Sedat, J. (1986). Spatial organization of chromosomes in the salivary gland nuclei of Drosophila melanogaster. J. Cell Biol. 102, 112-123.

Hochstrasser, M. and Sedat, J. W. (1987). Three-dimensional organization of Drosophila melanogaster interphase nuclei. II. Chromosome spatial organization and gene regulation. J. Cell Biol. 104, 1471-1483.

Ingham, P. W., Howard, K. R. ANd Ish-Horowicz, D. (1985). Transcription pattern of the Drosophila segmentation gene hairy. Nature 318, 439-445.

JACKSON, S. P. AND TIJAN, R. (1988). O-glycosylation of eukaryotic transcription factors: implications for mechanisms of transcriptional regulation. Cell 55, 125-133.

Karim, F. D. AND Thummel, C. S. (1991). Ecdysone coordinates the timing and amounts of $E 74 A$ and $E 74 B$ transcription in Drosophila. Genes Dev. 5, 1067-1079.

Karim, F. D., Urness, L. D., Thummel, C. S., Klemsz, M. J., McKercher, S. R., Celada, A., Van Beveren, C., Maki, R. A., Gunther, C. V., Nye, J. A. and Graves, B. J. (1990). The ETS-domain: a new DNA-binding motif that recognizes a purine-rich core DNA sequence. Genes Dev. 4, 1451-1453.

Kellerman, K., MatTson, D. M. and Duncan, I. (1990). Mutations affecting the stability of the fushi tarazu protein of Drosophila. Genes Dev. 4, 1936-1950.

KozAK, M. (1989). The scanning model for translation: an update. J. Cell Biol. 108, 229-241.

KuHN, R., SCHÄFER, U. AND SChäFER, M. (1988). Cis-acting regions sufficient for spermatocyte-specific transcriptional and spermatid-specific translational control of the Drosophila melanogaster gene mst(3)gl-9. EMBO J. 7, 447-454.

Lawrence, J. B., Singer, R. H. and Marselle, L. M. (1989). Highly localized tracks of specific transcripts within interphase nuclei visualized by in situ hybridization. Cell 57, 493-502.

LeMaire, M. F. AND Thummel, C. S. (1990). Splicing precedes polyadenylation during Drosophila E74A transcription. Molec. cell. Biol. 10, 6059-6063.

Macdonald, P. M. and Struhl, G. (1986). A molecular gradient in early Drosophila embryos and its role in specifying the body pattern. Nature 324, 537-545.

Maroni, G. and Stamey, S. C. (1983). Use of blue food to select synchronous, late third instar larvae. Dros. Inf. Serv. 59, 142-143.

Mrlner, M. J., Bleasby, A. J. and Kelly, S. L. (1984). The role of the peripodial membrane of leg and wing imaginal discs of Drosophila melanogaster during evagination and differentiation in vitro. Wilhelm Roux' Arch. devl Biol. 193, 180-186.

Mlodzik, M., BaKer, N. E. And Rubin, G. M. (1990). Isolation and expression of scabrous, a gene regulating neurogenesis in Drosophila. Genes Dev. 4, 1848-1861.

MlodziK, M. And Gehring, W. J. (1987). Expression of the caudal gene in the germ line of Drosophila: formation of an RNA and protein gradient during early embryogenesis. Cell $\mathbf{4 8 ,}$ 465-478.

Mylin, L. M., Johnston, M. And Hopper, J. E. (1990). Phosphorylated forms of GAL4 are correlated with ability to activate transcription. Molec. cell. Biol. 10, 4623-4629.

O'Connell, P. AND Rosbash, M. (1984). Sequence, structure, and codon preference of the Drosophila ribosomal protein 49 gene. Nucl. Acids Res. 12, 5495-5513.

Ollo, R. And Maniatis, T. (1987). Drosophila Krüppel gene product produced in a baculovirus expression system is a nuclear phosphoprotein that binds to DNA. Proc. natn Acad. Sci. U.S.A. 84, 5700-5704.

Pelletier, J. And Sonenberg, N. (1988). Internal initiation of translation of eukaryotic mRNA directed by a sequence derived from poliovirus RNA. Nature 334, 320-325.

Pelling, C. (1972). Transcription in giant chromosome puffs. In Developmental Studies on Giant Chromosomes, 4 (ed. W. Beerman) pp. 87-99. New York: Springer-Verlag.

ReCHSTEINER, M. (1988). Regulation of enzyme levels by proteolysis: the role of PEST regions. Adv. in Enzyme Reg. 27, 135-151.

Restifo, L. L. ANd Guild, G. M. (1986). Poly(A) shortening of coregulated transcripts in Drosophila. Devl Biol. 115, 507-510. 
RichaRds, G. (1981). Insect hormones in development. Biol. Rev. 56, 501-549.

RichaRDS, G. (1982). Sequential gene activation by ecdysteroids in polytene chromosomes of Drosophila melanogaster. VII. Tissue specific puffing. Wilhelm Roux' Arch. devl Biol. 191, 103-111.

Riggleman, B., Schedl, P. and Wieschaus, E. (1990). Spatial expression of the Drosophila segment polarity gene armadillo is posttranscriptionally regulated by wingless. Cell $\mathbf{6 3}, 549-560$.

Rio, D. C., LASKI, F. A. AND Rubin, G. M. (1986). Identification and immunochemical analysis of biologically active Drosophila $\mathrm{P}$ element transposase. Cell 44, 21-32.

RoBERTSON, C. W. (1936). The metamorphosis of Drosophila melanogaster including an accurately timed account of the principal morphological changes. J. Morph. 59, 351-399.

Rouault, T. A., Hentze, M. W., Caughman, S. W., Harford, J. B. AND KLAusner, R. D. (1988). Binding of a cytosolic protein to the iron-responsive element of human ferritin messenger RNA. Science 241, 1207-1210.

Sambrook, J., Fritsch, E. F. ANd Maniatis, T. (1989). Molecular Cloning - A Laboratory Manual. Cold Spring Harbor, New York: Cold Spring Harbor Laboratory Press.

Segraves, W. A. (1988). Molecular and genetic analysis of the
E75 ecdysone-responsive gene of Drosophila melanogaster. $\mathrm{Ph}$.D. thesis, Stanford University, Stanford, California.

Tautz, D. And Pfeifle, C. (1989). A non-radioactive in situ hybridization method for the localization of specific RNAs in Drosophila embryos reveals translational control of the segmentation gene hunchback. Chromosoma 98, 81-85.

Thummel, C. S., Burtis, K. C. And Hogness, D. S. (1990). Spatial and temporal patterns of E74 transcription during Drosophila development. Cell 61, 101-111.

URness, L. D. AND Thummel, C. S. (1990). Molecular interactions within the ecdysone regulatory hierarchy: DNA binding properties of the Drosophila ecdysone-inducible E74A protein. Cell 63, 47-61.

Walker, V. K. And Ashburner, M. (1981). The control of ecdysterone-regulated puffs in Drosophila salivary glands. Cell 26, 269-277.

White, K. And Kankel, D. (1978). Patterns of cell division and cell movement in the formation of the imaginal nervous system in Drosophila melanogaster. Devl Biol. 65, 296-321.

(Accepted 22 April 1991) 